\title{
Sources of anthropogenic contamination of soil in the Upper Silesian Agglomeration (southern Poland)
}

\author{
Anna PASIECZNA ${ }^{1}$, Agnieszka KONON ${ }^{1, *}$ and Weronika NADŁONEK ${ }^{2}$ \\ 1 Polish Geological Institute - National Research Institute, Rakowiecka 4, 00-975 Warszawa, Poland \\ 2 Polish Geological Institute - National Research Institute, Królowej Jadwigi 1, 41-200 Sosnowiec, Poland
}

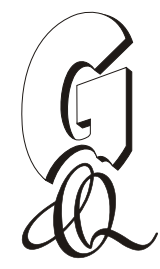

Pasieczna, A., Konon, A., Nadłonek, W., 2020. Sources of anthropogenic contamination of soil in the Upper Silesian Agglomeration (southern Poland). Geological Quarterly, 64 (4): 988-1003, doi: 10.7306/gq.1564

\begin{abstract}
This assessment of the environmental degradation by toxic chemical elements within the Upper Silesian Industrial Agglomeration of Poland encompasses the impact of mining for base metals and coal and non-ferrous metallurgy, as well as the discharge of industrial and municipal sewage causing strong degradation of the natural environment in the area over the years. The content of the following elements: Ag, Al, As, Ba, Ca, Cd, Co, Cr, Cu, Fe, Hg, Mg, Mn, Mo, Ni, P, Pb, S, Sn, Sr, Ti, $\mathrm{V}$ and $\mathrm{Zn}$ has been assessed both in the topsoil $(0.0-0.3 \mathrm{~m})$ and the subsoil $(0.8-1.0 \mathrm{~m})$ of the study area. Concentrations of the elements in the $<2 \mathrm{~mm}$ soil fraction were analysed using the ICP-OES method after Aqua regia extraction. The soil contamination was assessed based on the enrichment factor $(E F)$ and geo-accumulation index $\left(I_{\text {geo }}\right)$. The tests revealed elevated contents of several metals, arsenic and sulphur, exceeding the regional geochemical background levels. Unusually high concentrations of the following elements: As (up to 5,300 mg/kg), Cd (up to $388.8 \mathrm{mg} / \mathrm{kg}$ ), Cr (up to 1,638 mg/kg), Cu (up to $13,230 \mathrm{mg} / \mathrm{kg}$ ), $\mathrm{Hg}$ (up to $23.44 \mathrm{mg} / \mathrm{kg}$ ), Mo (up to $93.7 \mathrm{mg} / \mathrm{kg}$ ), Pb (up to $54,940 \mathrm{mg} / \mathrm{kg}$ ), Sn (up to $701 \mathrm{mg} / \mathrm{kg}$ ) and Zn (up to $88,120 \mathrm{mg} / \mathrm{kg}$ ) were recorded. The highest concentrations of these elements were found in the proximity of smelters and residential areas. The spatial distribution of metals is shown as interpolated data on maps and compared with the locations of mining and industrial sites.
\end{abstract}

Key words: soil pollution, toxic elements, enrichment factor $(E F)$, geo-accumulation index $\left(I_{g e o}\right)$, Upper Silesian Agglomeration (southern Poland).

\section{INTRODUCTION}

Degradation of the natural environment is at the present time the most acute problem of humanity. Pollution of soil by metals in industrial districts all over the world is one of the most serious issues that are directly affecting human health and biota (Basta and Gradwohl, 1998; De Volder et al., 2003; Wong et al., 2006; Wuana and Okieimen, 2011; Barbieri et al., 2014). Pollution of urban residential areas adjoining the sites of current or former base metal mines, steelworks of iron and nonferrous metal smelters has been shown to be highly hazardous (Basta et al., 2001; Basta and McGowen, 2004; Nachtegaal et al., 2005; Kachenko and Singh, 2006; Pelfrêne et al., 2011). Many elements and compounds hazardous to human and animal health have been found in the soils of these areas (Everhart et al., 2006; Filippelli and Laidlaw, 2010; Filippelli et al., 2012; Nannoni et al., 2011). Worsening crop conditions and the growth of deleterious microorganisms have also been documented (Fernandez-Turie et al., 2001; Cui et al., 2004; Friesl-Hanl et al., 2009; Nagajyoti et al., 2010; Klimek et al., 2016).

\footnotetext{
* Corresponding author, e-mail: agnieszka.konon@pgi.gov.pl
} Received: June 25, 2020; accepted: September 10, 2020; first published online: Ocober 27, 2020
Mining of base metals and the metallurgy industry cause dramatic increases in soil contamination in many agglomerations across the world, and among the greatest hazards is the impact of waste from this activity (Fuge et al., 1993; Swennen et al., 1994; Adamo et al., 2002; Cappuyns et al., 2005; Navarro et al., 2006; Taylor et al., 2010; Acosta et al., 2011). Potentially toxic elements (PTE) hazardous to ecosystems and human health penetrate soil as a result of weathering of metallurgy wastes and due to discharges of industrial sewage to water bodies and aquifers (Paulson, 1997; Gäbler and Schneider, 2000; Alloway, 2012). The harmful effects of arsenic, chromium, nickel, mercury, cadmium, copper, lead, zinc and of many organic compounds of ores and auxiliary raw materials of the steel industry, such as coke, have been demonstrated (Alloway, 2012; Filippelli et al., 2012). PTE are bound to soil components in various ways, which determines their mobility and availability (Kabata-Pendias and Mukherije, 2007), and the characteristic feature of anthropogenically contaminated soils is the presence of $30-60 \%$ of heavy metals in readily available forms (Karczewska et al., 1998).

The Upper Silesian Agglomeration of Southern Poland serves as an example of this phenomenon. Centuries of industrial activities in this area, which have included mining for coal and base metals as for $\mathrm{Pb}$ and $\mathrm{Zn}$, as well as non-ferrous metallurgy, have caused strong degradation of the natural environment and can cause extremely negative effects on the natural environment of this most populated agglomeration in Poland 
( 370 residents $/ \mathrm{km}^{2}$ compared to the country's average of 124 residents $/ \mathrm{km}^{2}$ ). Reclaimed post-industrial soils of considerable thickness and extent (Michalik, 2003; Sordoń-Kulibaba, 2010) that cover artificial slopes, heaps and some allotment gardens, as well as cultivated alluvial plains (Duriasz and Cupiał, 2009) are among the most vulnerable.

Mining for base metals, and the metallurgy of lead-zinc ores, has played the greatest role in the Upper Silesia economy since the 1800s (Lis and Pasieczna, 1995; Piwocki and Przeniosło, 2004). In the 1900s the iron technologies took over in the region and became one of the leading industries in Europe (Szulc, 2013). Exploitation of base metals and utilization of coal produced piles of gangue; slag and other waste stored in the immediate vicinity of smelters and residential areas caused pollution of the soils and aquifers. The ubiquitous presence of pollutants in the surface environment is detectable even several hundred years after the cessation of the initial industrial activity.

This study identifies and evaluates the sources of anthropogenic contamination, and interprets the distribution patterns of heavy metals, arsenic and sulphur in soils of the central part of the Upper Silesian Agglomeration that includes parts of the cities of Zabrze, Bytom, Ruda Śląska, Świętochłowice, Chorzów, Siemianowice Ślaskie and Katowice.

\section{OCCURRENCES AND COMPOSITION OF ECONOMIC MINERALS}

The study area is located in the Polish part of the Upper Silesia Region (Fig. 1). The region is known largely for the rich Upper Carboniferous coal deposits (Buła and Kotas, 1994; Jureczka et al., 2005) excavated in many underground mines. The quality parameters of the coal are highly diverse. Its ash content is in the range of $2-44 \%$ and the sulphur content is from 0.08 to $2.5 \%$. There are traces of $\mathrm{As}, \mathrm{Be}, \mathrm{Cd}, \mathrm{Co}, \mathrm{Cu}, \mathrm{Mn}, \mathrm{Pb}$ and $\mathrm{Zn}$ in the mineral fraction of coal, and $\mathrm{Hg}$ and $\mathrm{Mo}$ in the organic matter.

Besides the coal there are many $\mathrm{Zn}-\mathrm{Pb}$ ore deposits excavated in many locations across the district. The large $\mathrm{Zn}-\mathrm{Pb}$ ore deposits, of the Mississippi Valley type, exploited in the past from Triassic ore-bearing dolomites, belonged among the richest ones in the world (Górecka, 1993, 1996; Szuwarzyński, 1996; Viets et al., 1996; Heijlen et al., 2003; Kucha, 2003). Bog iron has also been locally exploited by surface mining (Molenda, 1972; Grzechnik, 1978). Nowadays, it is still possible to find traces of old mining excavations and waste heaps.

The mineral composition of the sulphide and oxidized ores exploited is relatively simple and includes sphalerite ( $\mathrm{ZnS}$ ), galena $(\mathrm{PbS})$, marcasite and pyrite $\left(\mathrm{FeS}_{2}\right.$; Górecka, 1996; Sass-Gustkiewicz, 1997). Trace amounts of lead-arsenic sulphosalts in the form of jordanite and gratonite are also noted (Harańczyk, 1962; Ziętek-Kruszewska, 1978; Górecka, 1996; Viets et al., 1996; Cabała, 1996, 2009). Gangue minerals include carbonates, silica and clay minerals (Cabała, 2009). Numerous trace elements are associated with the ore minerals. Zinc sulphide contains cadmium, silver, cobalt, copper, thallium and germanium. The galena is usually argentiferous (Harańczyk, 1962; Ekiert, 1971). The ores also contain arsenic and antimony compounds. The cadmium concentration in the sphalerite of the Silesian-Kraków deposits attains 5,000-10,000 mg/kg (Viets et al., 1996; Cabała, 2009). Iron sulphides may contain up to $1,000 \mathrm{mg} / \mathrm{kg}$ thallium and $\sim 500 \mathrm{mg} / \mathrm{kg}$ arsenic (Paulo and Strzelska-Smakowska, 2000). Silver is found within the crystal structure of sulphides, but most

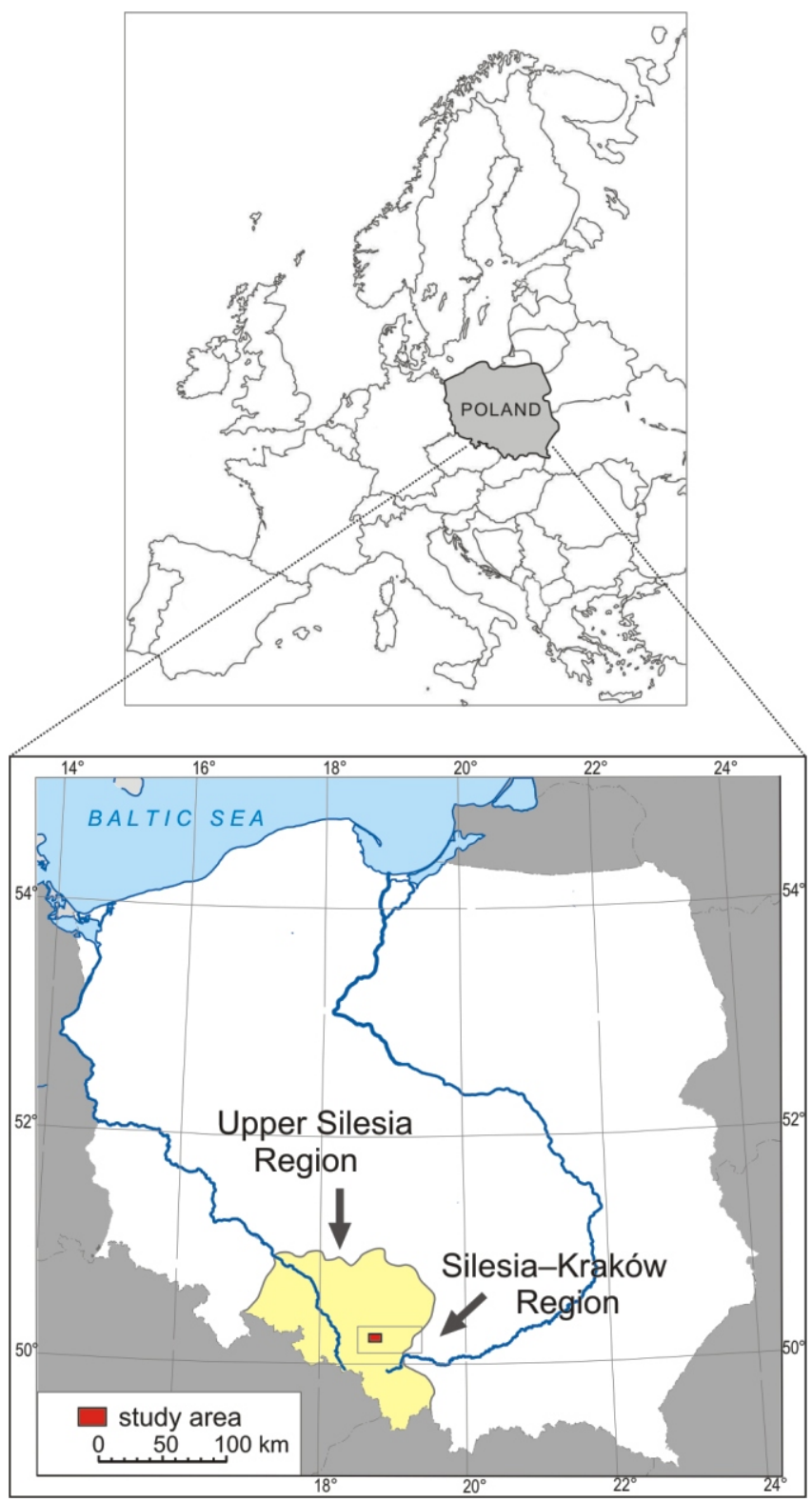

Fig. 1. Location of the study area

often it is associated with sphalerite (up to $3310 \mathrm{ppm}$ ) and much less with galena (up to 730 ppm; Mikulski et al., 2020). The main components of the oxidized deposits (galman) are carbonate minerals of zinc (smithsonite, monheimite) and lead (cerussite). They are accompanied by limonite aggregates and in places by sulphate minerals (jarosite, melanterite), hydrozincite and calcite (Żabiński, 1960; Cabała, 2009). In the northwestern part of the study area, barite has been found in fractures within Carboniferous rocks, as well as in sulphide and galman ores (Gałkiewicz and Śliwiński, 1985).

\section{HISTORY OF POLLUTION AND DEGRADATION}

Considerable anthropogenic pollution has been recorded across the entire study area occupied by mining. Due to the location of industrial facilities, extensive infrastructure and in- 
tense urbanisation, agricultural soils occur over very small areas, mainly of allotment gardens. In these areas, the natural components of soils are mixed with foreign materials, often repeatedly cultivated, watered and desiccated.

The natural environment has suffered contamination and degradation predominantly as a result of hard coal mining (Szczepańska and Twardowska, 1999), and the metallurgical (Kierczak et al., 2010; Tyszka et al., 2014), chemical and energy industries (Smieja-Król and Bauerek, 2015). The most intensive development of the area dates back to the 1900 s, although $\mathrm{Ag}$ and $\mathrm{Pb}$ and $\mathrm{Fe}$ ores have been extracted at several locations already since the 1600s (Molenda, 1972; Grzechnik, 1978). Mining of coal begun in the 1800 s and was followed by the establishment of iron and zinc smelters in this area. With the development of the railway network, the iron and zinc smelters expanded their facilities, and development of power plants, machinery industry, metal products and other industries took place. Part of the metals in the soils of the north-eastern part of the study area may originate from weathering of outcropping $\mathrm{Zn}-\mathrm{Pb}$ ore-bearing dolomites that were extracted in the past.

The soil is polluted mainly by: (1) historical exploitation and smelting of $\mathrm{Zn}-\mathrm{Pb}$ ore, (2) steel industry activity, (3) impact of mining waste (gangue heaps, sludge settlers, coal slurry, mine water; Bauerek et al., 2009), (4) impact of steel (slag and oily mill scales), energy and chemical industry waste, (5) particulate matter emissions from industrial plants (Jablonska et al., 2001; Dombek et al., 2015) and (6) transportation. The dissemination of contaminants penetrating the soil is sometimes facilitated by the use of mining waste for the reclamation of brown field sites, and by road construction and water engineering. The results of soil monitoring have shown that the permissible limits of metal concentrations are dramatically exceeded (Pasieczna, 2016). Iron-smelting waste heaps are located near the steelworks and smelters. These are predominantly of slag with minor amounts of moulding sand, refractory debris, sludge and post-treatment sediments. Slag is used as road aggregate. The largest mining waste heaps are located near closed and active coalmines.

\section{MATERIALS AND METHODS}

\section{SAMPLING AND SAMPLE PREPARATION}

Soil in the study area is developed on Carboniferous and Triassic bedrock as well as on Quaternary deposits. The predominant types are podzols and pseudopodzols developed on Carboniferous sandstones and on Quaternary fluvioglacial deposits. The parent material for cambisols and luvisols are glacial tills. Rendzinas occur in the areas of Triassic limestone and dolomite. Large areas are covered by anthropogenic soils formed in reclaimed post-industrial areas or naturally vegetated post-mining areas (Michalik, 2003; Sordoń-Kulibaba, 2010).

Soil samples were collected based on a regular grid of 250 $\times 250 \mathrm{~m}$ (16 samples per $\mathrm{km}^{2}$ ) in the years 2013-2014. At every site, the samples were collected from two intervals: $0.0-0.3 \mathrm{~m}$ (topsoil) and 0.8-1.0 m (subsoil). The total of topsoil samples was 2,806 and of subsoil samples 2,242 . The soil samples $(\sim 500 \mathrm{~g})$ were collected using a $60 \mathrm{~mm}$ hand probe. They were air dried and sieved through a $2 \mathrm{~mm}$ mesh.

\section{ANALYTICAL METHODS}

PHYSICOCHEMICAL PROPERTIES OF THE SOILS

The $<2 \mathrm{~mm}$ fraction was used for the $\mathrm{pH}$ determination of topsoil and subsoil, as well as total organic carbon (TOC) and the granulometric composition of the topsoil. The $\mathrm{pH}$ was determined using dry soil and deionised water (PN-ISO 10 390, 1997). The TOC content was measured using high-temperature combustion with infrared spectrometric detection (with the detection limit $0.01-0.02 \%$ ). The granulometric composition of topsoil was carried out combining sieve analysis with laser diffraction for fine material. The $<2 \mathrm{~mm}$ fraction samples were sieved through a set of $1-\mathrm{mm}$ and $0.5 \mathrm{~mm}$ sieves. The $2-1 \mathrm{~mm}$, $1.0-0.5 \mathrm{~mm}$ and $<0.5 \mathrm{~mm}$ fractions obtained were weighed. Measurements of grains from the $<0.5 \mathrm{~mm}$ fraction were made with a laser particle size analyser. Their results cannot therefore be used to classify the soils according to soil science criteria. However, they are very helpful when interpreting the geochemical results.

\section{CHEMICAL ANALYSES}

The $<2 \mathrm{~mm}$ fraction of the soil samples for chemical analyses was pulverized in agate planetary ball mills to a grain size of $<0.06 \mathrm{~mm}$. After digestion of the samples with hot aqua regia the concentrations of $\mathrm{Ag}, \mathrm{Al}, \mathrm{As}, \mathrm{Ba}, \mathrm{Ca}, \mathrm{Cd}, \mathrm{Co}, \mathrm{Cr}, \mathrm{Cu}, \mathrm{Fe}$, $\mathrm{Mg}, \mathrm{Mn}, \mathrm{Ni}, \mathrm{P}, \mathrm{Pb}, \mathrm{S}, \mathrm{Sn}, \mathrm{Sr}, \mathrm{Ti}, \mathrm{V}$ and $\mathrm{Zn}$ were determined using the ICP-OES method. The content of $\mathrm{Hg}$ was determined using the CV-AAS method with FIAS-100 with a flow injection system.

The quality control of the analyses was checked using duplicate samples (5\% of all samples), analysis of laboratory control samples confirming correct instrument calibration (5\% of all samples), certified standards ( $2 \%$ of all samples), and blanks. The expanded uncertainty of results (with an assumed probability level of $95 \%$ and coverage factor $k=2$ ) does not exceed $25 \%$.

\section{DATA ANALYSIS}

\section{STATISTICAL ANALYSIS}

Calculation of statistical parameters of the elements was performed for the whole sets of topsoil and subsoil, as well as for the subsets (forests, farmlands, urban parks, residential areas and industrial areas). The geochemical background in the Upper Silesian Agglomeration and the Silesia-Kraków Region was calculated as Median + 2 Median Absolute Deviation (MAD), which is relatively robust against the effect of data outliers that are common in geochemical datasets (Reimann et al., 2005; Reimann and de Caritat, 2017). The regional geochemical background (in the Silesia-Kraków Region) was calculated based on a database for the "Detailed geochemical map of Upper Silesia" (22,663 topsoil samples and 19,307 subsoil samples). In the case of some elements with background contents lower than the detection limit value for a given analytical method, half of the detection limit value was applied.

Factor Analysis $(F A)$ and Principal Component Analysis $(P C A)$ were used in segregating sources (lithogenic, anthropogenic or mixed) contributing to the pollution observed (Lis and Pasieczna, 2005; Lu et al., 2012; Guo-Li et al., 2013). Using matrices obtained after Varimax rotation, three factors of eigenvalues $>1$ were distinguished within both topsoil and subsoil sample sets, important for the interpretation of results.

GEOCHEMICAL INDICES

In order to assess the soil contamination around the Upper Silesian Agglomeration, the enrichment factor $(E F)$ of topsoil and subsoil and the geoaccumulation index $\left(I_{\text {geo }}\right)$ of topsoil were used. These indices are widely used for the estimation of geo- 
chemical anomalies and anthropogenic impact on soil chemistry, which refers to the enrichment degree of metal concentrations in soils investigated relative to uncontaminated background levels (baseline; Loska et al., 2004; Barbieri, 2016).

The enrichment factor $(E F)$ was calculated for topsoil and subsoil:

$$
E F=(C / X)_{\text {sample }} /(C / X)_{\text {median for Upper Silesian Agglomeration }}
$$

where: $C$ - the chemical element investigated, $X$ - the reference element that is predominantly bound in silicate minerals, geochemically conservative and resistant to chemical alteration during earth surface processes.

The most common reference elements are $\mathrm{Al}, \mathrm{Fe}, \mathrm{Mn}$, Sc and Ti (Reimann and de Caritat, 2000; Sutherland et al., 2000). This study uses $\mathrm{Ti}$ as the reference element for the calculation of $E F$. It is assumed that an $E F$ value of $\sim 1$ indicates a geogenic origin of the element. Values within the ranges of $1.5-3,3-5$ and $>5$ point to, respectively, minimal, moderate and significant changes in the environment, where the chemical element origin is other than natural (Blaser et al., 2000; Sutherland et al., 2000; Zhang and Liu 2002; Loska et al., 2004).

The geoaccumulation index $\left(I_{g e o}\right)$ was originally defined and used for assessing metal concentrations in sediments (Müller, 1969), but it is also used to determine the condition of soils (Loska et al., 2004; Barbieri, 2016). This index is calculated according to the formula:

$$
I_{\text {geo }}=\log _{2}(A / 1.5 \times B)
$$

where: $A$ - measured concentration of the element in the sample, $B$ - median for the Upper Silesian Agglomeration.

The factor 1.5 in the formula is introduced to reduce the lithology-related variability in the geochemical baseline. The geoaccumulation index enables the classification of soils as follows: $I_{\text {geo }} \leq 0$ uncontaminated; $0 \leq I_{\text {geo }} \leq 1$ uncontaminated to moderately contaminated; $1 \leq I_{\text {geo }} \leq 2$ moderately contaminated; $2 \leq I_{\text {geo }} \leq 3$ moderately to heavily contaminated; $3 \leq I_{\text {geo }} \leq 4$ heavily contaminated; $4 \leq I_{\text {geo }} \leq 5$ heavily to extremely contaminated; $I_{\text {geo }}>5$ extremely contaminated (Loska et al., 2004; Barbieri, 2016).

GEOCHEMICAL MAPPING

The spatial distributions of some elements in topsoil and subsoil are depicted in maps compiled using kriging as a method of interpolation and percentiles to define the distribution classes.

\section{RESULTS AND DISCUSSION}

\section{PHYSICOCHEMICAL PROPERTIES OF THE SOIL}

The topsoil samples analysed show a wide range of properties such as $\mathrm{pH}$ (from very acidic to alkaline), TOC content $(0.05-55.90 \%)$ and granulometric composition (from sand to clay) indicating their significant transformation (Table 1).

The largest area of strongly alkaline topsoil $(\mathrm{pH}>8)$ covers the central, most industrialized part of the Upper Silesian Agglomeration (Figs. 2-4) and the areas located near currently active metal smelters. Alkaline $\mathrm{pH}$ also prevails in the subsoil of these areas, which shows the influence of anthropogenic alkalizing factors to considerable depths. One of the causes of the soil alkalisation is the long-term emission of particulate matter from metal plants and combustion of coal in which the $\mathrm{CaO}$ content can reach 10\% (Zapotoczna-Sytek et al., 2013). Other alkalising factors include agents used for snow removal from streets $\left(\mathrm{CaCl}_{2}, \mathrm{MgCl}_{2}\right)$, periodic dust transfer from mine, slag and furnace waste dumps, and dispersion of dust from small quarries of Triassic limestone and dolomite extracted for local needs. A higher proportion of alkaline subsoil can be associated with a greater amount of alkalising materials (construction and industrial waste) and the proximity of local carbonate rocks in the deep parts of the soil profiles.

The lowest TOC content $(<3 \%)$ was found in topsoil developed on Quaternary sandy deposits. In the soils developed on Quaternary glacial tills and Triassic carbonates, the content of this constituent commonly varies between 3 and $6 \%$. Values of $>6 \%$ are typical of soils in urban and industrial areas. Around hard coal mines, the TOC content exceeds $12 \%$, locally even $24 \%$. The mean value of TOC content in farmland topsoil is $2.8 \%$, in urban parks $3.4 \%$, in residential areas $4.6 \%$, in forests $6.4 \%$, and in industrial areas $7.2 \%$.

The grain size distribution of the topsoil is clearly related to the parent lithology. Carboniferous sandstones and Pleistocene fluvioglacial sands are the main parent material of soils containing $40-80 \%$ of the sand fraction, which typically also contain $<20 \%$ of silt and $<10 \%$ of clay. This soil covers predominantly the south-western part of the mapped area. Soils that developed on Pleistocene glacial tills are rich in silt, commonly in excess of $40 \%$. This is accompanied by clay, usually accounting for $10-15 \%$. Soil that are rich in silt and clay and have higher metal concentrations prevail in the central and north-eastern parts of the map area.

\section{CONCENTRATIONS OF SELECTED ELEMENTS IN SOIL}

Comparison of the geochemical background values of the elements studied in the soils of the Upper Silesian Agglomera-

$$
\text { Table } 1
$$

Statistical values of physicochemical parameters of the topsoil

\begin{tabular}{|l|c|c|c|c|c|}
\hline \multirow{2}{*}{} & \multirow{2}{*}{$\mathrm{pH}$} & TOC & $\begin{array}{c}\text { Sand } \\
1.0-0.1 \mathrm{~mm}\end{array}$ & $\begin{array}{c}\text { Silt } \\
0.1-0.02 \mathrm{~mm}\end{array}$ & $\begin{array}{c}\text { Clay } \\
<0.02 \mathrm{~mm}\end{array}$ \\
\cline { 3 - 6 } & & \multicolumn{5}{|c|}{$\%$} \\
\hline Range & $4.0-10.4$ & $0.05-55.90$ & $0-96.7$ & $0.1-99.9$ & $0.1-99.9$ \\
\hline Average & 7.4 & 5.41 & 32.8 & 49.0 & 16.4 \\
\hline Median & 7.6 & 3.71 & 30.6 & 55.4 & 14.4 \\
\hline
\end{tabular}



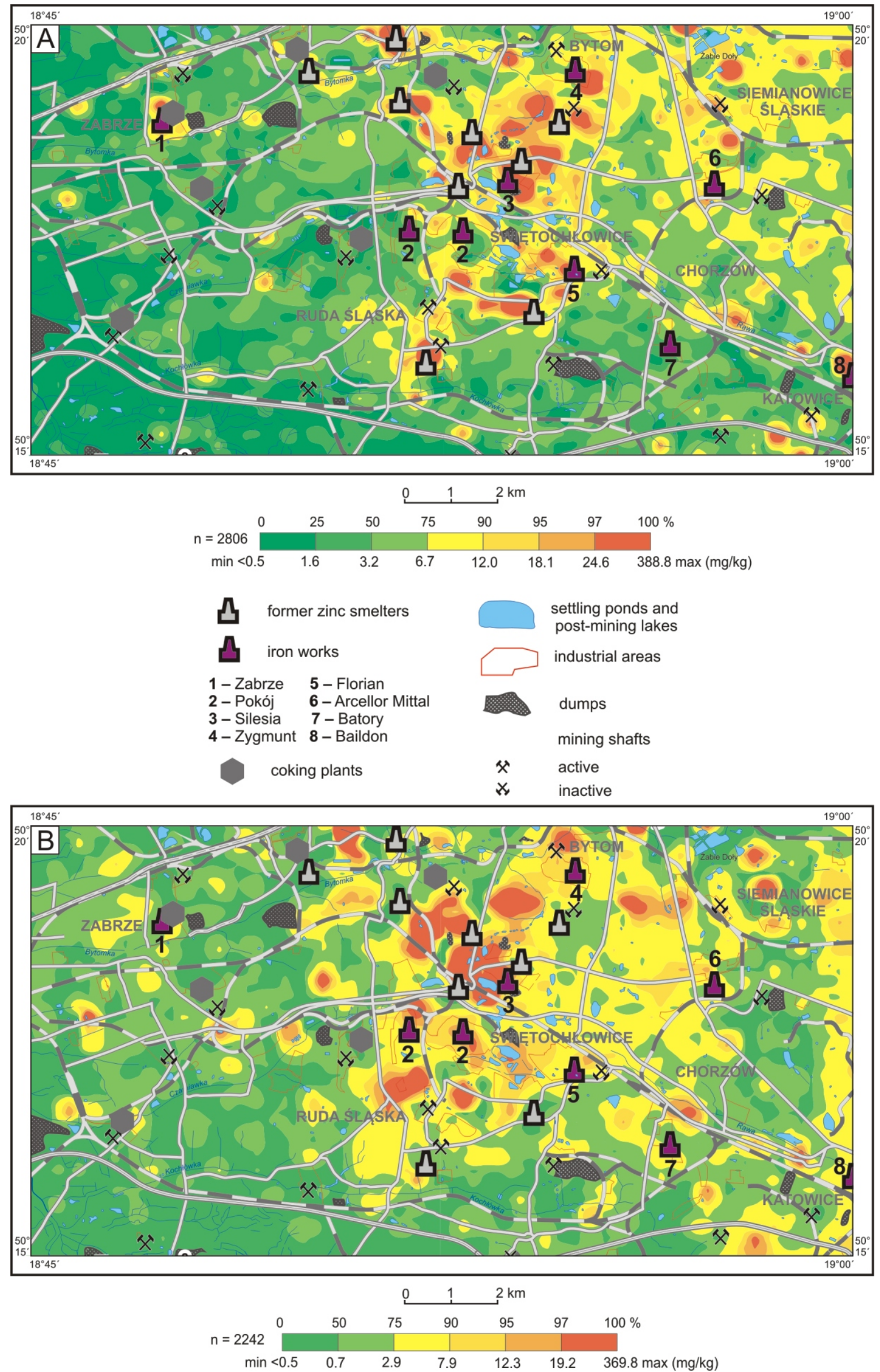

Fig. 2. Cadmium content in topsoil (A) and subsoil (B) 

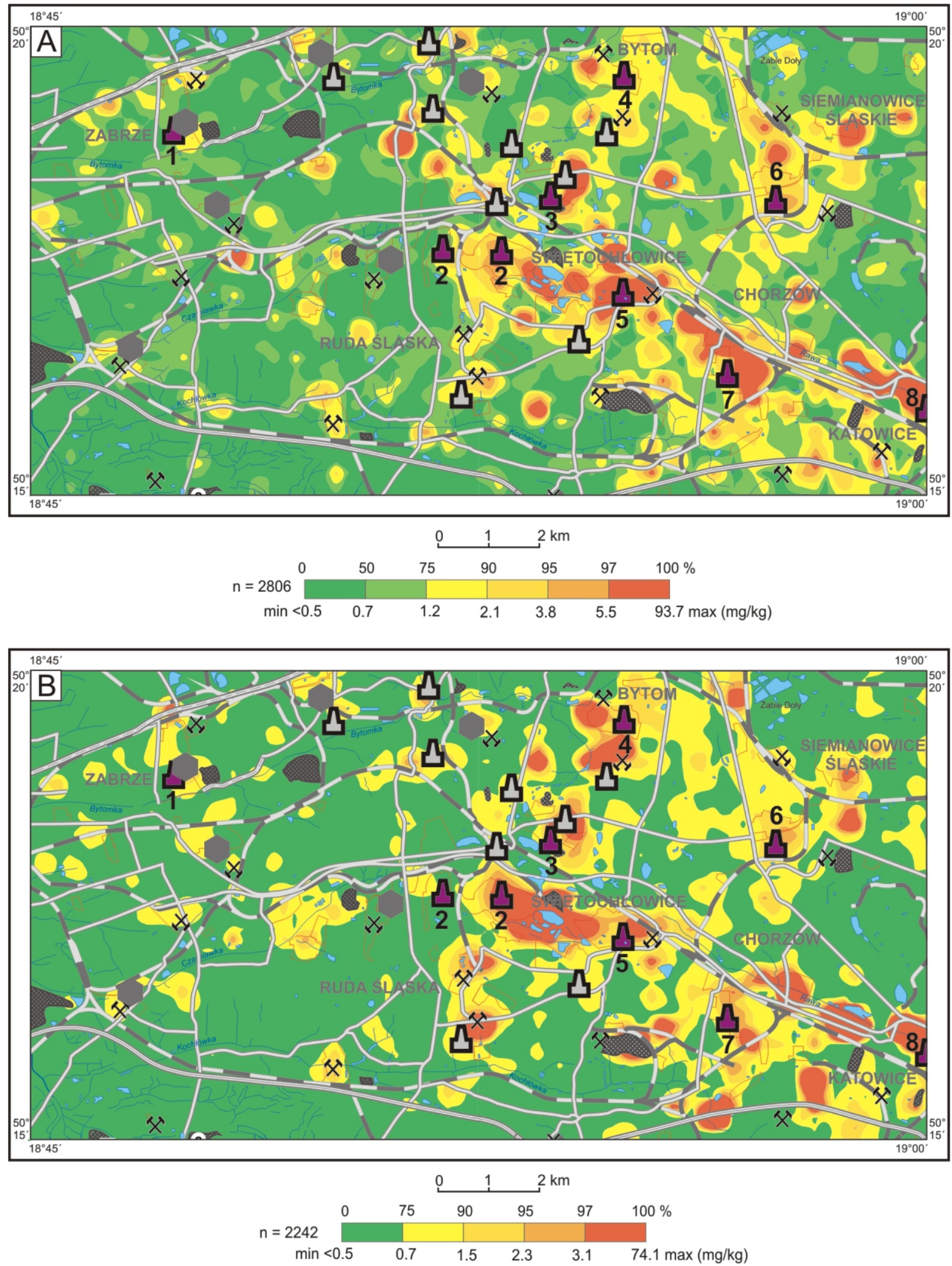

Fig. 3. Molybdenum content in topsoil (A) and subsoil (B)

Explanations as in Figure 2 


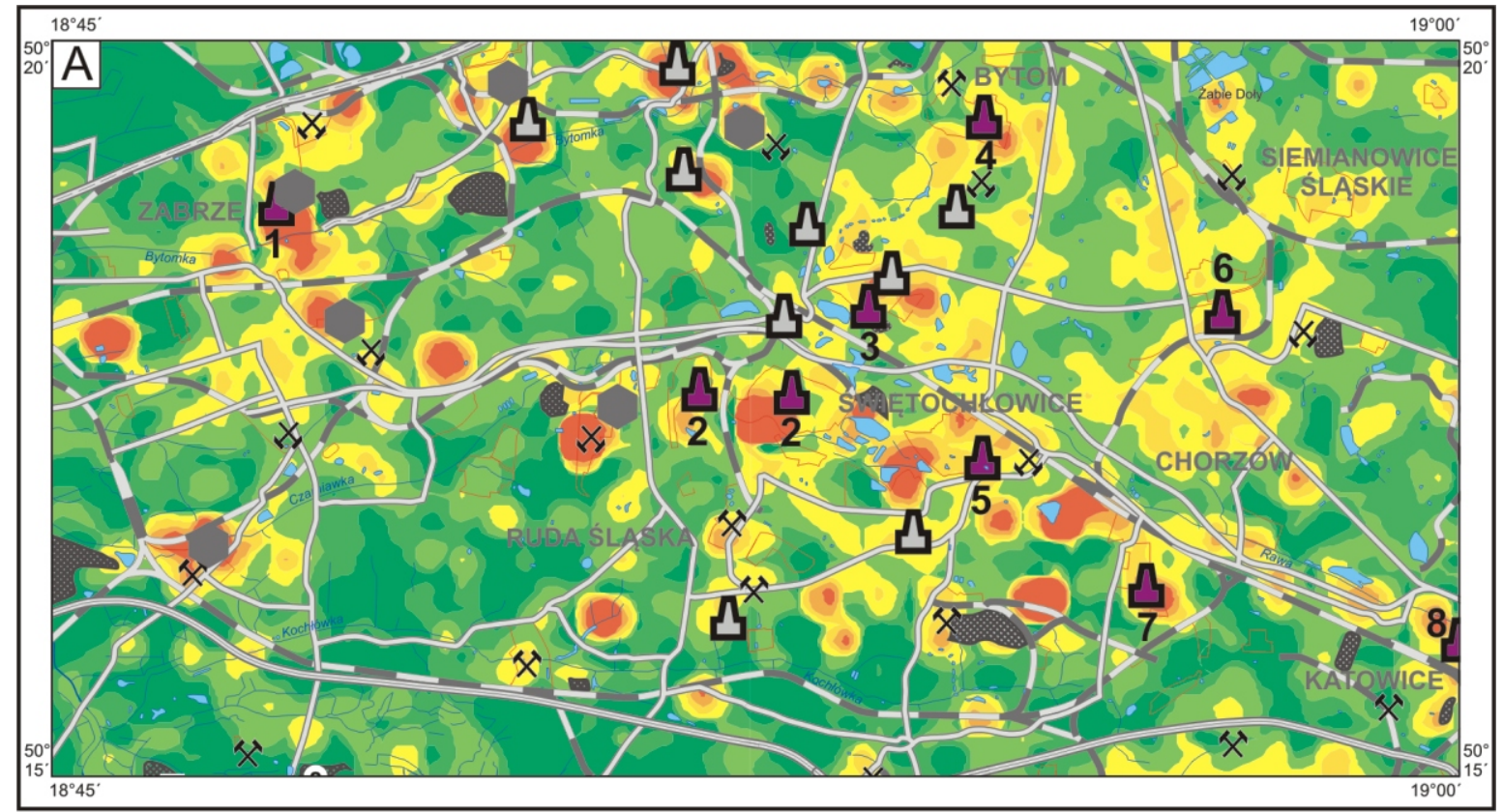

$0 \quad 1 \quad 2 \mathrm{~km}$
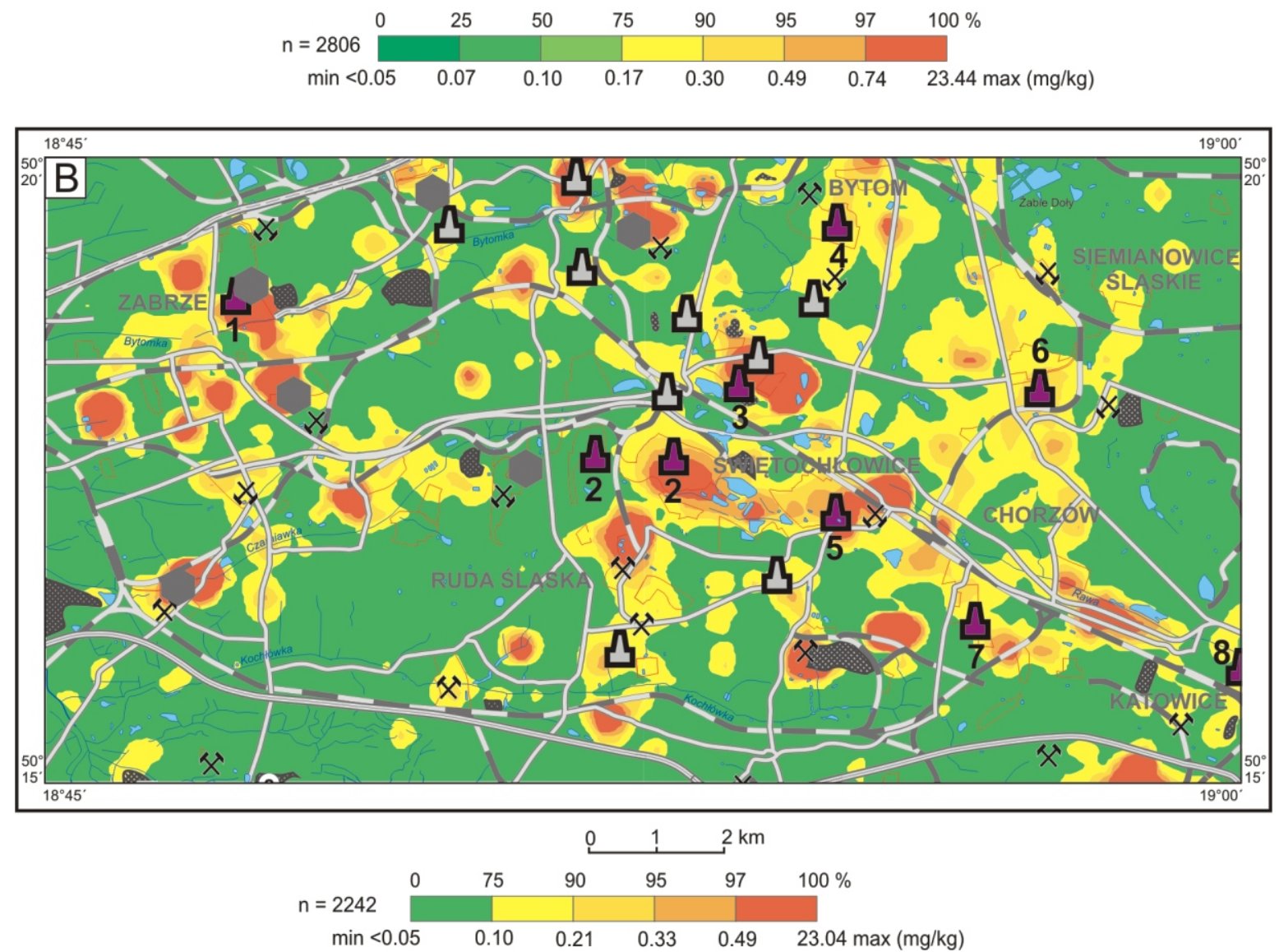

Fig. 4. Mercury content in topsoil (A) and subsoil (B)

Explanations as in Figure 2 
Table 2

Statistical parameters of the chemical elements analysed

\begin{tabular}{|c|c|c|c|c|c|c|c|c|c|}
\hline \multirow{3}{*}{ Element } & \multirow{3}{*}{$\begin{array}{l}\text { Detection } \\
\text { limit }\end{array}$} & \multicolumn{6}{|c|}{ *Upper Silesian Agglomeration } & \multicolumn{2}{|c|}{$\begin{array}{c}* \text { Silesia-Kraków Region } \\
(\text { Pasieczna, 2016) }\end{array}$} \\
\hline & & \multirow{2}{*}{$\begin{array}{l}\text { Range } \\
\mathrm{mg} / \mathrm{kg}\end{array}$} & \multirow[t]{2}{*}{ Mean } & \multirow[t]{2}{*}{ Median } & $\begin{array}{l}{ }^{* * *} \text { Geoche- } \\
\text { mical back- } \\
\text { ground }\end{array}$ & SD & CV (\%) & Median & $\begin{array}{l}{ }^{* * *} \text { Geochemi- } \\
\text { cal background }\end{array}$ \\
\hline & & & & & \multicolumn{5}{|c|}{$\mathrm{mg} / \mathrm{kg}$} \\
\hline \multirow{2}{*}{$\mathrm{Ag}$} & \multirow{2}{*}{1} & $<1-97$ & $<1$ & $<1$ & - & 2.7 & - & $<1$ & - \\
\hline & & $<1-86$ & $<1$ & $<1$ & - & 2.9 & - & $<1$ & - \\
\hline \multirow{2}{*}{ As } & \multirow{2}{*}{3} & $<3-5288$ & 26 & 10 & 19 & 149.3 & 574 & 6 & 12 \\
\hline & & $<3-5300$ & 17 & 4 & 10 & 133.5 & 785 & $<3$ & - \\
\hline \multirow{2}{*}{$\mathrm{Ba}$} & \multirow{2}{*}{1} & $4-1830$ & 221 & 172 & 334 & 168.7 & 76 & 59 & 128 \\
\hline & & $9-1869$ & 150 & 72 & 160 & 194.4 & 130 & 28 & 56 \\
\hline \multirow{2}{*}{$\mathrm{Cd}$} & \multirow{2}{*}{0.5} & $<0.5-388.8$ & 6.4 & 3.2 & 7 & 16.1 & 252 & 2 & 5 \\
\hline & & $<0.5-369.8$ & 4.0 & 0.7 & 4 & 17.5 & 438 & $<0.5$ & - \\
\hline \multirow{2}{*}{ Co } & \multirow{2}{*}{1} & $<1-218$ & 6 & 5 & 8 & 5.8 & 97 & 2 & 5 \\
\hline & & $1-61$ & 5 & 4 & 8 & 4.3 & 86 & 2 & 5 \\
\hline & & $<1-1317$ & 26 & 15 & 27 & 56.2 & 216 & 8 & 17 \\
\hline $\mathrm{Cr}$ & 1 & $1-1638$ & 17 & 12 & 26 & 44.5 & 262 & 5 & 12 \\
\hline$C_{11}$ & & $4-13230$ & 53 & 26 & 53 & 306.7 & 577 & 9 & 19 \\
\hline $\mathrm{Cu}$ & 1 & $1-2772$ & 28 & 11 & 25 & 86.1 & 308 & 4 & 10 \\
\hline & & $<0.05-23.44$ & 0.19 & 0.10 & 0.18 & 0.7 & 368 & 0.05 & 0.10 \\
\hline $\mathrm{Hg}$ & 0.05 & $<0.05-23.04$ & 0.14 & $<0.05$ & - & 0.7 & 500 & $<0.05$ & - \\
\hline & & $3-42380$ & 868 & 515 & 996 & 1956.1 & 225 & 242 & 646 \\
\hline IVIn & 2 & $3-37100$ & 247 & 519 & 859 & 1353.9 & 548 & 72 & 204 \\
\hline & & $<0.5-93.7$ & 1.4 & 0.7 & 1.6 & 4.3 & 307 & $<0.5$ & - \\
\hline Mo & 0.5 & $<0.5-74.1$ & 0.8 & $<0.5$ & - & 2.6 & 325 & $<0.5$ & - \\
\hline & 1 & $<1-433$ & 18 & 13 & 25 & 21.6 & 120 & 6 & 14 \\
\hline $\mathrm{NI}$ & 1 & $1-587$ & 14 & 9 & 19 & 22.1 & 158 & 4 & 10 \\
\hline & & $4-54940$ & 307 & 137 & 287 & 1398.4 & 456 & 72 & 152 \\
\hline PD & 2 & $<2-17890$ & 172 & 30 & 68 & 811.8 & 472 & 11 & 28 \\
\hline & & $<2-701$ & 5 & 2 & 4 & 16.5 & 330 & $<2$ & - \\
\hline Sn & 2 & $<2-361$ & 3 & $<2$ & - & 12.6 & 420 & $<2$ & - \\
\hline $\mathrm{Sr}$ & 1 & $1-806$ & 51 & 33 & 71 & 59.1 & 116 & 9 & 21 \\
\hline sr & 1 & $<1-921$ & 37 & 14 & 33 & 64.1 & 173 & 4 & 8 \\
\hline $\mathrm{Ti}$ & 5 & $7-4086$ & 126 & 96 & 173 & 144.9 & 115 & 74 & 132 \\
\hline 11 & 5 & $19-2480$ & 116 & 89 & 145 & 101.4 & 87 & 69 & 129 \\
\hline v & 1 & $1-225$ & 22 & 19 & 30 & 16.8 & 76 & 12 & 24 \\
\hline V & 1 & $1-268$ & 17 & 15 & 29 & 13.8 & 81 & 8 & 19 \\
\hline & 1 & $8-55460$ & 454 & 479 & 1104 & 2678.0 & 590 & 164 & 405 \\
\hline$\angle \mathrm{n}$ & 1 & $3-88120$ & 720 & 108 & 258 & 3445.2 & 479 & 33 & 78 \\
\hline & & & & & $\%$ & & & & \\
\hline$\Delta !$ & & $0.05-4.33$ & 0.67 & 0.64 & 0.96 & 0.3 & 44 & 0.49 & 0.95 \\
\hline Al & 0.01 & $0.07-2.50$ & 0.64 & 0.60 & 1.02 & 0.3 & 47 & 0.40 & 0.88 \\
\hline $\mathrm{Ca}_{3}$ & 001 & $<0.01-27.61$ & 0.99 & 0.53 & 1.30 & 1.4 & 141 & 0.16 & 0.44 \\
\hline Ca & 0.01 & $<0.01-16.60$ & 0.75 & 0.20 & 0.50 & 1.4 & 187 & 0.05 & 0.14 \\
\hline $\mathrm{Fe}$ & $0 \cap 1$ & $0.05-34.30$ & 1.82 & 1.40 & 2.44 & 1.9 & 104 & 0.69 & 1.55 \\
\hline re & 0.01 & $0.02-20.43$ & 1.37 & 1.06 & 2.36 & 1.5 & 109 & 0.41 & 1.06 \\
\hline $\mathrm{Ma}$ & 001 & $<0.01-6.38$ & 0.26 & 0.16 & 0.33 & 0.4 & 154 & 0.07 & 0.18 \\
\hline IVIg & 0.01 & $<0.01-9.33$ & 0.21 & 0.12 & 0.26 & 0.5 & 238 & 0.05 & 0.13 \\
\hline$P$ & בח० & $0.003-0.510$ & 0.050 & 0.041 & 0.072 & 0.04 & 80 & 0.028 & 0.039 \\
\hline$P$ & 0.002 & $<<0.002-0.600$ & 0.028 & 0.019 & 0.043 & 0.04 & 143 & 0.009 & 0.021 \\
\hline $\mathrm{s}$ & $0 \cap 03$ & $<0.003-8.790$ & 0.074 & 0.038 & 0.073 & 0.26 & 351 & 0.022 & 0.046 \\
\hline 3 & 0.003 & $<0.003-5.960$ & 0.053 & 0.012 & 0.024 & 0.21 & 396 & 0.006 & 0.013 \\
\hline & & Topsoil ( $n=28$ & & & & & $(n=22$ & 63) & \\
\hline & & Subsoil $(n=22$ & & & & & il $(n=19$, & 07) & \\
\hline
\end{tabular}


tion and the Silesia-Kraków Region (Table 2) shows that their concentration in the study area is clearly related to the location of anthropogenic sources. The topsoil reveals more than/or almost threefold enrichment in $\mathrm{Ca}, \mathrm{Sr}$ and $\mathrm{Zn}$, and over twofold enrichment in $\mathrm{Cu}, \mathrm{Ba}$ and $\mathrm{Zn}$, compared to the geochemical background levels in the Silesia-Kraków Region. In the subsoil, there is fourfold enrichment in $\mathrm{Mn}$ and $\mathrm{Sr}$ and over threefold enrichment in $\mathrm{Zn}$ and $\mathrm{Ca}$, as well over twofold enrichment in $\mathrm{Ba}$, $\mathrm{Cr}, \mathrm{Cu}, \mathrm{Fe}, \mathrm{P}$ and $\mathrm{Pb}$ as compared to the regional geochemical background levels.

The high values of standard deviation (SD) and coefficients of variability (CV) for most elements indicate high data dispersion in relation to the average values (Table 2). The low CV\% values $(<200)$ for $\mathrm{Al}, \mathrm{Ba}, \mathrm{Ca}$, Co Fe, Ni, P, Sr, Ti and V suggest that their distribution in the soils is relatively homogeneous, and that they are related mainly to lithogenic origin. In the case of As, $\mathrm{Cd}, \mathrm{Cr}, \mathrm{Cu}, \mathrm{Hg}, \mathrm{Mn}, \mathrm{Mo}, \mathrm{Pb}, \mathrm{S}, \mathrm{Sn}$ and $\mathrm{Zn}$, the high $\mathrm{CV} \%$ values indicate that these elements are characterized by inhomogeneous distribution suggesting that part of them might have been introduced artificially into the environment. The distribution of many elements derived mainly from the parent rocks has been disturbed by anthropogenic factors especially in the topsoil. Anthropogenic transformations have led to such significant changes in the chemical composition of the soils in relation to the parent rocks that the basic geochemical features of the original rocks in topsoil are difficult to discern.

The spatial distribution of $\mathrm{Cd}$, Mo and $\mathrm{Hg}$ in the soils of the Upper Silesian Agglomeration (Figs. 2-4) is quoted as an example of the presence of pollution originating from various industrial activities - zinc smelters, iron-steel factories and coking plants.

The concentration levels of $\mathrm{Cd}$ in topsoil and subsoil are similar: $<0.5-388.8 \mathrm{mg} / \mathrm{kg}$ and $<0.5-369.8 \mathrm{mg} / \mathrm{kg}$, respectively (Fig. 2) The contamination of soils by this potentially toxic element is a serious problem in some areas of the Upper Silesian Agglomeration (Chłopecka et al., 1996; Cabała and Teper, 2007) and elsewhere across the world (Alary et al., 1983; Moir and Thornton, 1989).

The highest contamination by $\mathrm{Cd}$ (Fig. 2) and $\mathrm{As}, \mathrm{Pb}, \mathrm{S}$ and $\mathrm{Zn}$ has been noted in the central part of the study area around former zinc smelters and their waste dump sites. The Cd concentration anomalies (>18.1 mg/kg) occupy smaller areas within topsoil compared to subsoil $(>12.3 \mathrm{mg} / \mathrm{kg}$ ), indicating easy migration of this element from the surface to deeper soil horizons, although comparison of the mean values of $\mathrm{As}, \mathrm{Pb}, \mathrm{S}$ and $\mathrm{Zn}$ indicates that topsoil is generally more enriched in these elements than is the subsoil (Table 2). A greater extent of these anomalies in subsoil is associated with both the texture of highly permeable soils (predominance of sandy soils) and the occurrence of unstable metal sulphates, indicating that the wastes remain intensely geochemically active even many years after production ceased (Merrington and Alloway, 1994; Cabała and Teper, 2007; Kabata-Pendias and Mukherjee, 2007; Rożek et al., 2015).

In the areas of $\mathrm{Cd}$ anomalies within both topsoil and subsoil, there are also strong $\mathrm{Pb}$ and $\mathrm{Zn}$ anomalies of similar spatial extent with concentrations of $>770 \mathrm{mg} / \mathrm{kg} \mathrm{Pb},>3,190 \mathrm{mg} / \mathrm{kg} \mathrm{Zn}$, and $>540 \mathrm{mg} / \mathrm{kg}$ and $>2,260 \mathrm{mg} / \mathrm{kg}$, respectively. Extreme values of these elements occur only on a local scale $(5 \%$ of soils analysed). The major sources of $\mathrm{As}, \mathrm{Cd}, \mathrm{Pb}, \mathrm{Zn}$ and $\mathrm{S}$ are the remaining $\mathrm{Zn}-\mathrm{Pb}$ ore piles and tailings heaps of some former small zinc smelters, although soils heavily polluted with these elements are also found near steelworks.

The Mo anomalies that occur in the study area around iron smelters and steelworks are very clearly marked in both topsoil $(>3.8 \mathrm{mg} / \mathrm{kg}$ ) and subsoil $(>2.3 \mathrm{mg} / \mathrm{kg})$, although the values are not high in most of the soil samples (Fig. 3). The Mo concentration is related to the activity of iron and steel industry plants, most of which are no longer active. Currently, there is only one blast furnace in the ArcelorMittal steelworks, producing pig iron from imported iron ores and steel scrap (Burchart-Korol, 2010). Due to the environmental requirements of current production, it affects the environment to a lesser extent than the former more harmful technologies.

In $75 \%$ of the topsoil and subsoil samples, the Mo concentrations are $<1.2 \mathrm{mg} / \mathrm{kg}$ and $<0.7 \mathrm{mg} / \mathrm{kg}$, respectively. The topsoil concentration of Mo is $<0.5-93.7 \mathrm{mg} / \mathrm{kg}$, and its subsoil concentration is $<0.5-74.1 \mathrm{mg} / \mathrm{kg}$ (Table 2). The environmental impact of technologies used in the production of steel is assessed primarily with respect to the emission of $\mathrm{CO}_{2}$ from metallurgical furnaces and organic compounds from coking plants. The elements occurring as admixtures in ores ( $\mathrm{As}, \mathrm{Zn}, \mathrm{Pb}$ ) and emitted mainly during ore sintering and smelting in electric furnaces, as well as steel refining metals (Mo, Cr, Ni, Sn, V, Zn) added in plants that manufacture special steels and coated products, e.g. galvanised zinc- and tin-plated sheets, etc., are also harmful (Burchart-Korol, 2010; Krzak and Paulo, 2018).

In the areas of Mo anomalies, the soil shows enrichments in $\mathrm{Cr}, \mathrm{Ni}$ and $\mathrm{Sn}$, most likely because these elements are frequently found in Mo-containing steels. Because of its resistance to high temperature, Mo is added to high-speed steel cutting tools, corrosion-resistant steels, and special alloys (Reimann and de Caritat, 1998; Smedley and Kinniburgh, 2017). The most contaminated soil occurs within a belt extending from Świętochłowice to Katowice. This is the Rawa River valley that, for decades, received industrial sewage from the Batory, Florian and Silesia steelworks, as well as leachates from their dumpsites and settling tanks. In a settling tank of one of no longer active steel mill, $200 \mathrm{mg} / \mathrm{kg} \mathrm{Mo}, 681 \mathrm{mg} / \mathrm{kg} \mathrm{Ni}, 132 \mathrm{mg} / \mathrm{kg}$ $\mathrm{Sn}$, and 2,420 $\mathrm{mg} / \mathrm{kg}$ Cu have been detected (Pasieczna et al., 2017).

An additional source of soil contamination by Mo in the area studied is burning of hard coal and storing of fly ash after combustion. Most of the hard coals have significant Mo contents, which in turn affects the content in the power plant ash, where there can be up to several tens $\mathrm{mg} / \mathrm{kg}$ of Mo (Pandey et al., 2009; Bhattacharyya et al., 2009; Deonarine et al., 2015), while its mobile fractions, which can be leached from ash under particular environmental conditions, account for $24 \%$ (Kalembkiewicz and Sočo, 2009). It is probable that the high mobility of Mo explains a much greater range of its anomalies in subsoil than in topsoil (Fig. 3). Even reclaimed landfills of such ashes pose a threat to the environment due to the potential migration of trace elements, including molybdenum.

Soil contaminated by $\mathrm{Hg}$ was found primarily in the vicinity of active and old coking plants and ironworks, as well as around mine shafts and waste heaps of hard coal mines (Fig. 4). In the natural environment, $\mathrm{Hg}$ is considered one of the most toxic metals, even at very low concentrations, due to its chemical and biological activity and the diversity of its forms of occurrence (Kabata-Pendias and Mukherjee, 2007; Rice et al., 2014). In the study area, $\mathrm{Hg}$ concentrations are in the range of $<0.05-23.44 \mathrm{mg} / \mathrm{kg}$ in topsoil, and $<0.05-23.04 \mathrm{mg} / \mathrm{kg}$ in subsoil (Table 2). The anomalies usually have a small spatial range in topsoil, and larger in subsoil. The soil contamination by $\mathrm{Hg}$ in the study area is high as compared to the concentration of $<0.05-7.55 \mathrm{mg} / \mathrm{kg}$ found across Poland (Lis and Pasieczna, 1995), Europe with $0.002-1.35 \mathrm{mg} / \mathrm{kg}$ (De Vos and Tarvainen, 2006) and European agricultural and grazing land soils with $<0.030-3.12 \mathrm{mg} / \mathrm{kg}$ (Ottesen at al., 2013).

The main source of $\mathrm{Hg}$ is certainly its dispersion when burning large amounts of hard coal. $\mathrm{Hg}$ is quite common in hard 
Principal Component Analysis (Varimax-normalized factor model); marked loads $>0.5$

\begin{tabular}{|c|c|c|c|c|c|c|}
\hline \multirow[b]{2}{*}{ Element } & \multicolumn{3}{|c|}{ Topsoil } & \multicolumn{3}{|c|}{ Subsoil } \\
\hline & $\begin{array}{c}\mathrm{F} 1 \\
\mathrm{Al}, \mathrm{Ba}, \mathrm{P}, \mathrm{Sr}\end{array}$ & $\begin{array}{c}\mathrm{F} 2 \\
\mathrm{Ag}, \mathrm{As}, \mathrm{Cd}, \mathrm{Pb}, \mathrm{S}, \mathrm{Zn}\end{array}$ & $\begin{array}{c}\mathrm{F} 3 \\
\mathrm{Cr}, \mathrm{Mo}, \mathrm{Ni}\end{array}$ & $\begin{array}{c}\mathrm{F} 1 \\
\mathrm{Al}, \mathrm{Ba}, \underset{\mathrm{Ti}, \mathrm{V}}{\mathrm{Co}} \mathrm{V}, \mathrm{P}, \mathrm{Sr},\end{array}$ & $\frac{\mathrm{F} 2}{\mathrm{Ag}, \mathrm{As}, \mathrm{Cd}, \mathrm{Pb}, \mathrm{S}, \mathrm{Zn}}$ & $\begin{array}{c}\mathrm{F} 3 \\
\mathrm{Cr}, \mathrm{Mo}, \mathrm{Ni}\end{array}$ \\
\hline $\mathrm{Ag}$ & 0.104 & 0.624 & 0.049 & 0.051 & 0.607 & 0.069 \\
\hline $\mathrm{Al}$ & 0.664 & 0.056 & 0.160 & 0.880 & 0.078 & 0.050 \\
\hline As & -0.003 & 0.812 & 0.009 & 0.088 & 0.705 & 0.038 \\
\hline $\mathrm{Ba}$ & 0.817 & 0.049 & 0.065 & 0.602 & -0.036 & 0.061 \\
\hline $\mathrm{Ca}$ & 0.238 & 0.232 & 0.118 & 0.351 & 0.283 & 0.093 \\
\hline $\mathrm{Cd}$ & 0.101 & 0.798 & 0.113 & 0.037 & 0.843 & 0.029 \\
\hline Co & 0.428 & 0.156 & 0.419 & 0.752 & 0.154 & 0.280 \\
\hline $\mathrm{Cr}$ & -0.016 & -0.067 & 0.769 & 0.153 & -0.042 & 0.924 \\
\hline $\mathrm{Cu}$ & 0.017 & 0.051 & 0.027 & 0.213 & 0.294 & 0.202 \\
\hline $\mathrm{Fe}$ & 0.314 & 0.288 & 0.499 & 0.607 & 0.395 & 0.386 \\
\hline $\mathrm{Hg}$ & 0.098 & 0.030 & 0.032 & 0.107 & 0.068 & 0.029 \\
\hline $\mathrm{Mg}$ & 0.052 & 0.325 & 0.230 & 0.239 & 0.361 & 0.084 \\
\hline $\mathrm{Mn}$ & 0.176 & 0.094 & 0.205 & 0.347 & 0.301 & 0.184 \\
\hline Mo & 0.029 & 0.039 & 0.872 & 0.129 & 0.107 & 0.923 \\
\hline $\mathrm{Ni}$ & 0.277 & 0.214 & 0.829 & 0.386 & 0.091 & 0.836 \\
\hline $\mathrm{P}$ & 0.709 & 0.058 & 0.058 & 0.526 & -0.036 & -0.031 \\
\hline $\mathrm{Pb}$ & 0.054 & 0.774 & 0.137 & 0.059 & 0.868 & 0.058 \\
\hline$S$ & -0.098 & 0.675 & -0.049 & 0.117 & 0.686 & 0.030 \\
\hline Sn & 0.107 & 0.093 & 0.110 & 0.111 & 0.185 & 0.084 \\
\hline $\mathrm{Sr}$ & 0.723 & 0.107 & 0.060 & 0.614 & 0.009 & 0.081 \\
\hline $\mathrm{Ti}$ & 0.474 & 0.003 & 0.199 & 0.627 & 0.013 & 0.099 \\
\hline $\mathrm{V}$ & 0.390 & 0.015 & 0.485 & 0.773 & 0.064 & 0.331 \\
\hline $\mathrm{Zn}$ & 0.132 & 0.865 & 0.069 & 0.045 & 0.898 & 0.020 \\
\hline Variance $\%$ & 31.20 & 13.00 & 7.38 & 33.49 & 14.32 & 8.49 \\
\hline Cumulative $\%$ & \multicolumn{3}{|c|}{50.58} & \multicolumn{3}{|c|}{56.30} \\
\hline
\end{tabular}

coal, both in organic and mineral matter (Diehl et al., 2004; Yudovich and Ketris, 2005; Kolker et al., 2006; Hławiczka, 2008; Gade, 2015).

Part of the $\mathrm{Hg}$ is probably related to its presence in iron sulphides, which are an admixture in $\mathrm{Zn}-\mathrm{Pb}$ ores (Bojakowska and Sokołowska, 2001). Hg can also be derived from compounds in wood preservatives (protecting railway sleepers). In garden plots, $\mathrm{Hg}$ anomalies can be the result of excessive use of insecticides. In other cases, mercury comes from the scrap of fluorescent lamps, $\mathrm{Zn}-\mathrm{HgO}$ batteries, fuses and devices formerly used in measuring and control instruments across many industries, and in the electrotechnical equipment of sodium-chloride plants (Szpadt, 1994; Paulo and Strzelska-Smakowska, 2000).

ASSESSMENT OF METAL POLLUTION OF SOILS AFFECTED BY DIFFERENT INDUSTRY TYPES AND DIFFERENT LAND USES

Grouping of chemical elements using Principal Component Analysis ( $P C A$ ) (Table 3 ) enables determination of their main sources.

Factor F1 (loading on Al, Ba, P, Sr) explained $31.2 \%$ of the total variance in topsoil and $33.49 \%$ of the total variance in subsoil (loading on $\mathrm{Al}, \mathrm{Ba}, \mathrm{Co}, \mathrm{Fe}, \mathrm{P}, \mathrm{Sr}, \mathrm{Ti}, \mathrm{V}$ ) can be related to a mixed lithological-anthropogenic origin of the elements. They are sourced primarily from soil parent materials. Both Quaternary glacial tills and Carboniferous mudstones-claystones have naturally elevated concentrations of $\mathrm{Al}, \mathrm{Co}, \mathrm{V}, \mathrm{Ba}, \mathrm{Fe}, \mathrm{P}$ and $\mathrm{Ti}$.
The sources of Sr are both the soils' parent materials and the discharges of mine water to watercourses, which increase the concentration of this element in river valley soils. Significant anthropogenic sources of $\mathrm{Ba}$ are also particles from coal combustion (Różkowska and Ptak, 1995) and leachates from waste heaps after industrial coal enrichment with the use of barite.

Factor F2 (loading on Ag, As, Cd, Pb, S and Zn) explained $13.0 \%$ of the total variance in topsoil and $14.32 \%$ in subsoil, suggesting that these elements were affected by anthropogenic (industrial) activities in addition to the natural content from weathered ore deposits. They are associated mainly with mining and processing of $\mathrm{Zn}-\mathrm{Pb}$ ores and with zinc metallurgy. The period of increased exploitation of $\mathrm{Zn}-\mathrm{Pb}$ ores and construction of mills for its processing began in the 19th century and lasted until the end-20th century. Initially, the main raw materials for the production of this metal were $\mathrm{Ag}$ and $\mathrm{Pb}$ smelting slags, then calaman deposits, and finally $\mathrm{Zn}-\mathrm{Pb}$ sulphide ores (Majorczyk, 1986). At different periods, zinc was produced in the following smelters: Marien Wunsch, Bobrek, Guidotto, Godulla, Konstancja, Constantin, Gabor, Klara and Dawid. Moreover, zinc-processing plants operated in the premises of the former Zygmunt iron smelter (at the beginning of its activity), and as one of the departments of the iron smelter in Chorzów (Degenhardt, 1870; Szczech, 2003).

Factor F3 (loading on $\mathrm{Cr}$, Mo and $\mathrm{Ni}$ ) explained $7.38 \%$ of the total variance in topsoil and $8.49 \%$ in subsoil. It can be considered mainly anthropogenic, grouping elements related to the iron and steel industry. The soil has been contaminated by both 

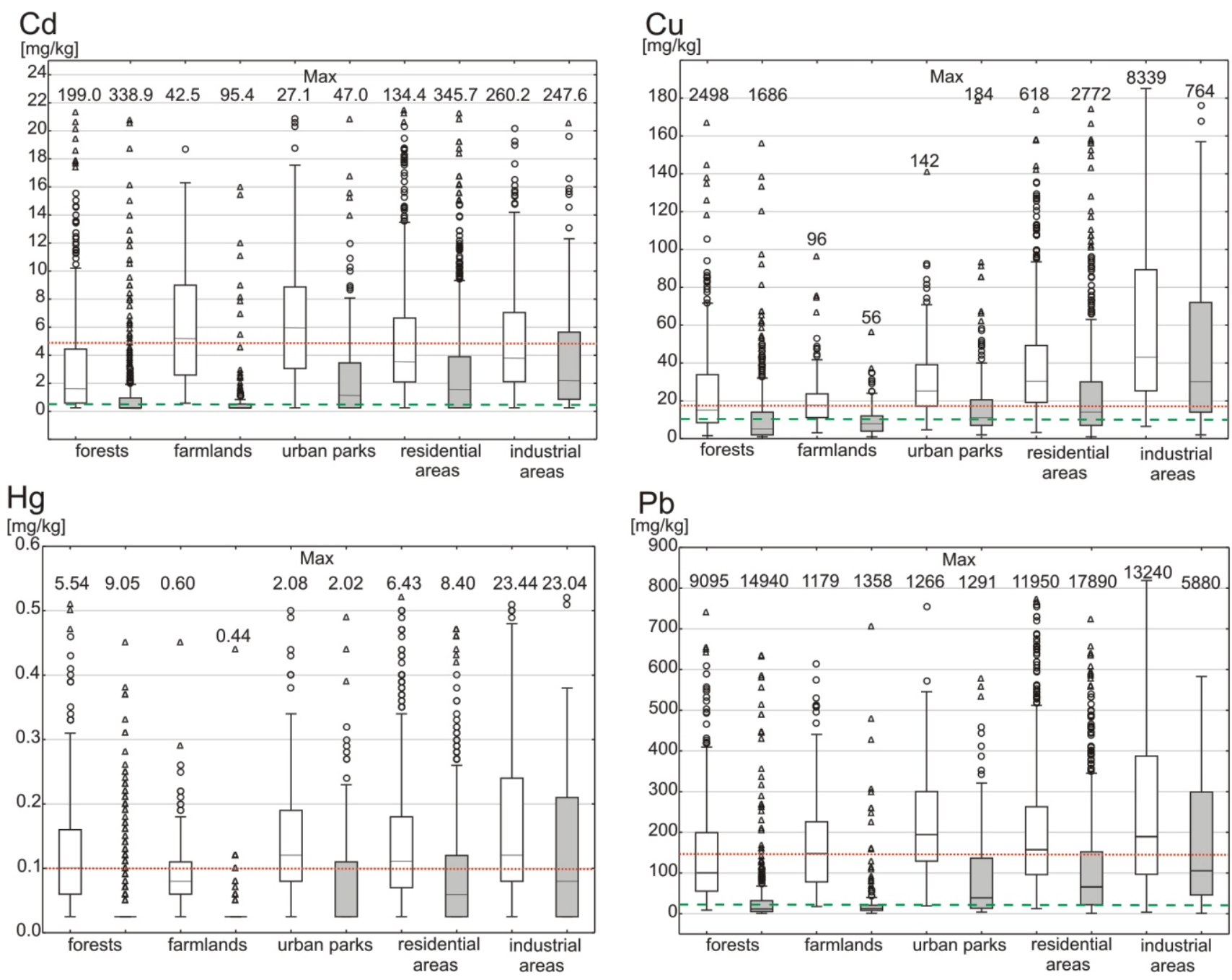

$\mathrm{Pb}$
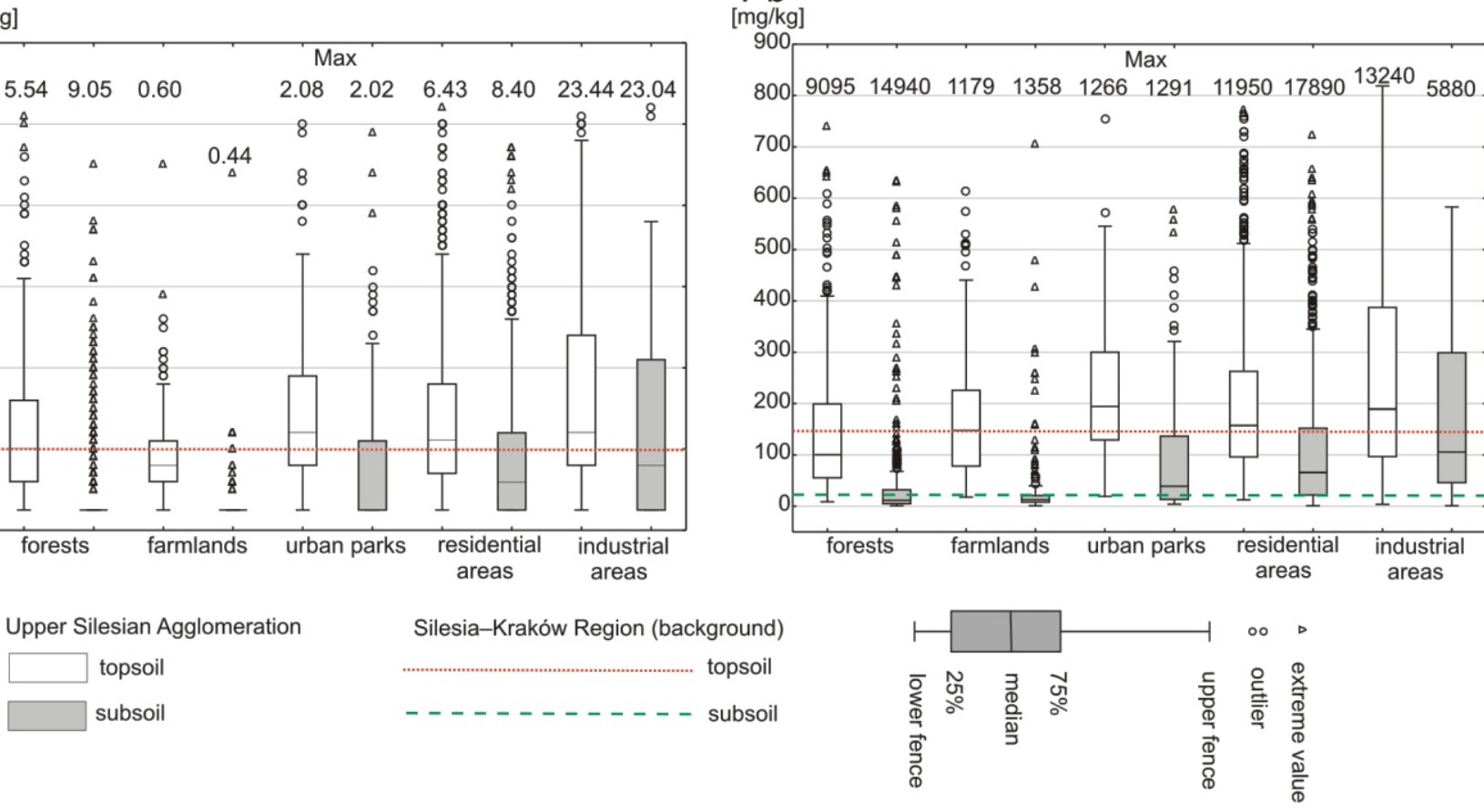

Fig. 5. Boxplots of the percentile classes of $\mathrm{Cd}, \mathrm{Cu}, \mathrm{Hg}$ and $\mathrm{Pb}$ in topsoil and subsoil

chemical elements from raw materials and production wastes (metallurgical slag, moulding materials, refractory rubble, and neutralisation and other types of sludge). The elements grouped by factor F3 have been dispersed from iron smelters for many years. In the area of the largest, Pokój steelworks, iron smelting was carried out as early as 1642. Later, the Antonienhütte and Bertha ironworks came into operation (Sulimierski et al., 1880-1914). The Pokój steelworks started production in 1840. Before the Second World War, it was the largest smelter in Poland and the only one that produced ferromanganese (Owczarek et al., 2012), which probably contributed to the concentration of $\mathrm{Fe}(>2 \%), \mathrm{Cr}(>40 \mathrm{mg} / \mathrm{kg})$ and $\mathrm{Mn}$ $(>1,600 \mathrm{mg} / \mathrm{kg})$ in the surrounding soils (Pasieczna, 2016). The Zabrze, Zygmunt, Florian, Batory and Silesia steelworks operated from the mid-19th century to the beginning of the 21st century (Niemierowski, 1983; Walerjański, 2006).

Single-element box plots of selected elements ( $\mathrm{Cd}, \mathrm{Cu}, \mathrm{Hg}$, $\mathrm{Pb}$ ) were used to demonstrate the concentration and degree of pollution in soils of forests, farmlands, urban parks, residential areas and industrial areas (Fig. 5). The land use includes predominantly scattered residential areas, including commercial and service buildings $-31 \%$, and industrial areas (mines, steelworks, metallurgical plants, landfills and mine heaps) $-11 \%$. Urban parks occupy $6 \%$, forests $16 \%$, and farmlands $7 \%$ of the area. Water reservoirs, roads, railway lines, transport bases and wasteland represent the remaining part of the area.

Comparison of box plot data of $\mathrm{Cd}, \mathrm{Cu}, \mathrm{Hg}$ and $\mathrm{Pb}$ with regional geochemical values of these elements in the Silesian-Kraków Region indicates that their greatest concentrations are found in topsoil of residential and industrial areas (Fig. 5). The median values of individual elements for topsoil are significantly higher than in subsoil in all land-use categories. This indicates that the enrichments result from non-geological sources.

When considering the position of boxes for $\mathrm{Cd}, \mathrm{Cu}, \mathrm{Hg}$ and $\mathrm{Pb}$ in different land uses, a further notable feature is the least contamination of subsoil in forests and farmlands. But in topsoil, the situation is more complicated, e.g. $25-75$ percentile $\mathrm{Cd}$ con- 


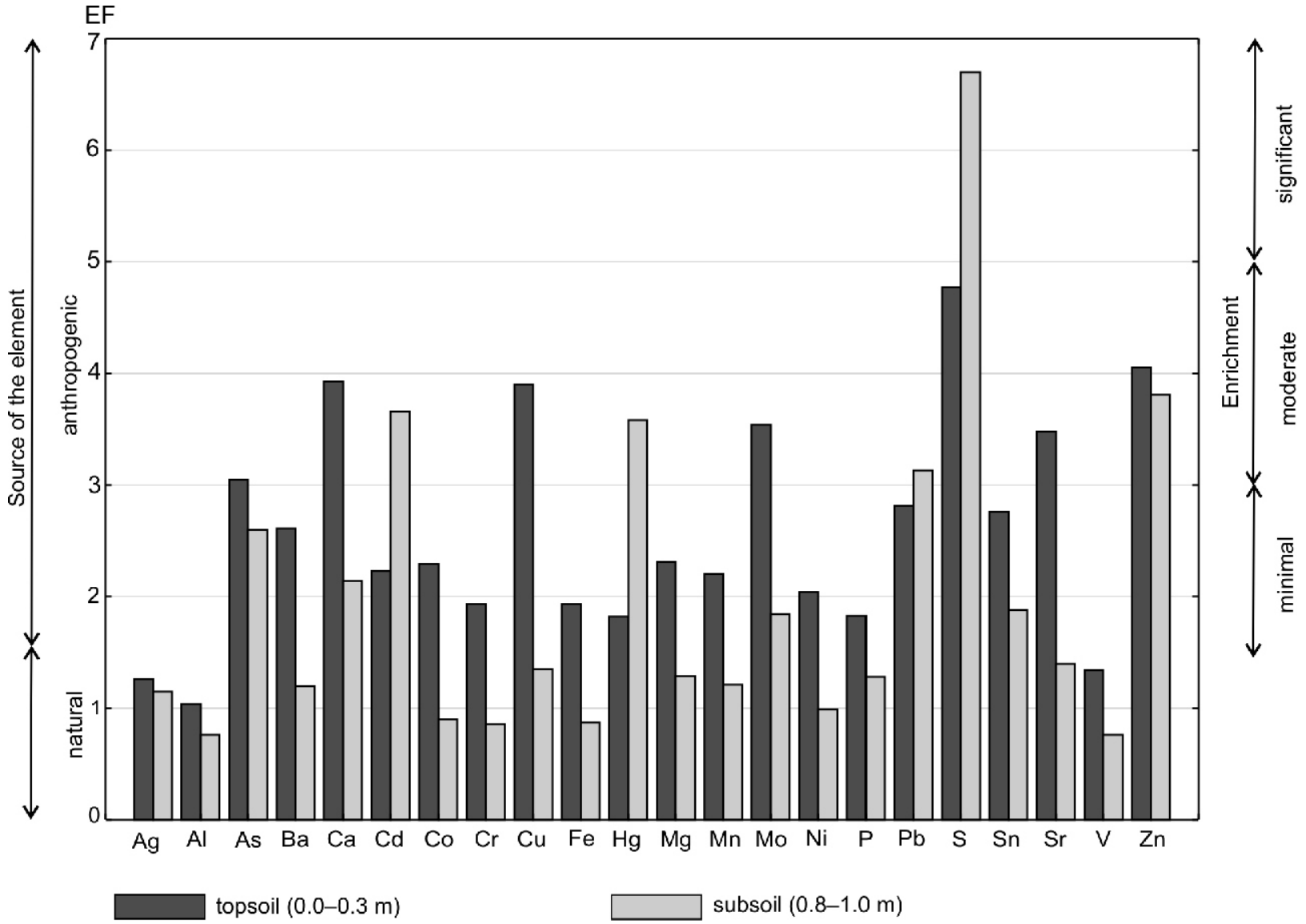

Fig. 6. Mean values of enrichment factors

centrations in urban parks and farmlands are higher than in industrial and residential areas. Maximum extreme values and 25-75 percentile of $\mathrm{Hg}, \mathrm{Cu}$ and $\mathrm{Pb}$ in topsoils shows the highest concentrations in industrial areas.

\section{GEOCHEMICAL INDICES}

The PCA results are supported by the EF values of the elements analysed (Fig. 6). Based on classification of EF values proposed by various authors (Blaser et al., 2000; Sutherland et al., 2000; Zhang and Liu, 2002; Loska et al., 2004) it can be concluded that a significant part of metals, arsenic and sulphur in the topsoil and subsoil of the Upper Silesian Agglomeration comes from anthropogenic sources. Assuming that values of EF $<1.5$ show both minor changes in soil chemistry and the lithogenic origin of the elements in topsoil, we can infer that Ag, $\mathrm{Al}$, and $\mathrm{V}$ definitely come from natural sources. These elements are accompanied in the subsoil by $\mathrm{Ba}, \mathrm{Co}, \mathrm{Cr}, \mathrm{Fe}, \mathrm{Mg}, \mathrm{Mn}, \mathrm{Ni}, \mathrm{P}$ and $\mathrm{Sr}$ originating primarily from parent materials. The highest EF values in the topsoil and subsoil were found for $\mathrm{S}, \mathrm{Zn}$ and $\mathrm{Pb}$, an this can be related to both the dispersion of these elements from industrial sources (especially in topsoil, which also accumulates As, $\mathrm{Ca}$, Mo and $\mathrm{Sr}$ ) and the presence of these metal sulphides in the parent materials of the soils (Triassic $\mathrm{Zn}-\mathrm{Pb}$ ore-bearing dolomites). Moderate or minimal enrichments in $\mathrm{Ca}, \mathrm{Cu}, \mathrm{Mo}, \mathrm{Sr}, \mathrm{Cd}$ and $\mathrm{Hg}$ have been seen both in the topsoil and subsoil (Fig. 6). The enrichment of the subsoil in Cd, $\mathrm{Hg}, \mathrm{Pb}$ and $\mathrm{S}$ vs topsoil is probably related to the presence of these elements in the form of finely dispersed $\mathrm{Zn}$ and $\mathrm{Pb}$ sulphides in the parent material.
The most useful assessment of topsoil contamination is the geoaccumulation index $\left(I_{\text {geo }}\right)$. The distribution of the $25-75$ percentile values and the $I_{\text {geo }}$ median of individual elements show the presence of the greatest accumulation of $\mathrm{Zn}, \mathrm{Pb}$ and $\mathrm{Ca}$ in topsoil as well as of $\mathrm{Sr}, \mathrm{Fe}, \mathrm{Mn}, \mathrm{Cu}, \mathrm{Cd}$ and S (Fig. 7). The maximum values of $I_{\text {geo }}$ indices for most of the elements analysed indicate strong and extreme contaminations that occur only at a few small locations. The lowest $\mathrm{I}_{\text {geo }}$ values are found for $\mathrm{Ag}, \mathrm{Al}$, $\mathrm{Ti}$, and $\mathrm{V}$.

\section{CONCLUSIONS}

1. Pollution history by base metals is documented in part in the study area. Some previously active but now forgotten locations of small zinc smelters and waste landfills have been inferred from these geochemical studies. The analyses performed show that chemical transformation of the soil in many regions is very advanced and anthropogenic changes have been recorded in all soil types that developed from different lithologies of the Carboniferous, Triassic and Quaternary successions.

2. Wide ranges of properties such as $\mathrm{pH}$ (from very acidic to alkaline), TOC content $(0.05-55.90 \%)$ and grain size distribution (from sandy to clayey soils) have been found in the topsoils studied.

3. The topsoil of the study area shows three-fold enrichment in $\mathrm{Ca}$ and $\mathrm{Sr}$, and/or more than twofold enrichment in $\mathrm{Cu}, \mathrm{Ba}$, and $\mathrm{Zn}$ compared to the geochemical background in the Silesia-Kraków Region. The subsoil shows four-fold enrich- 


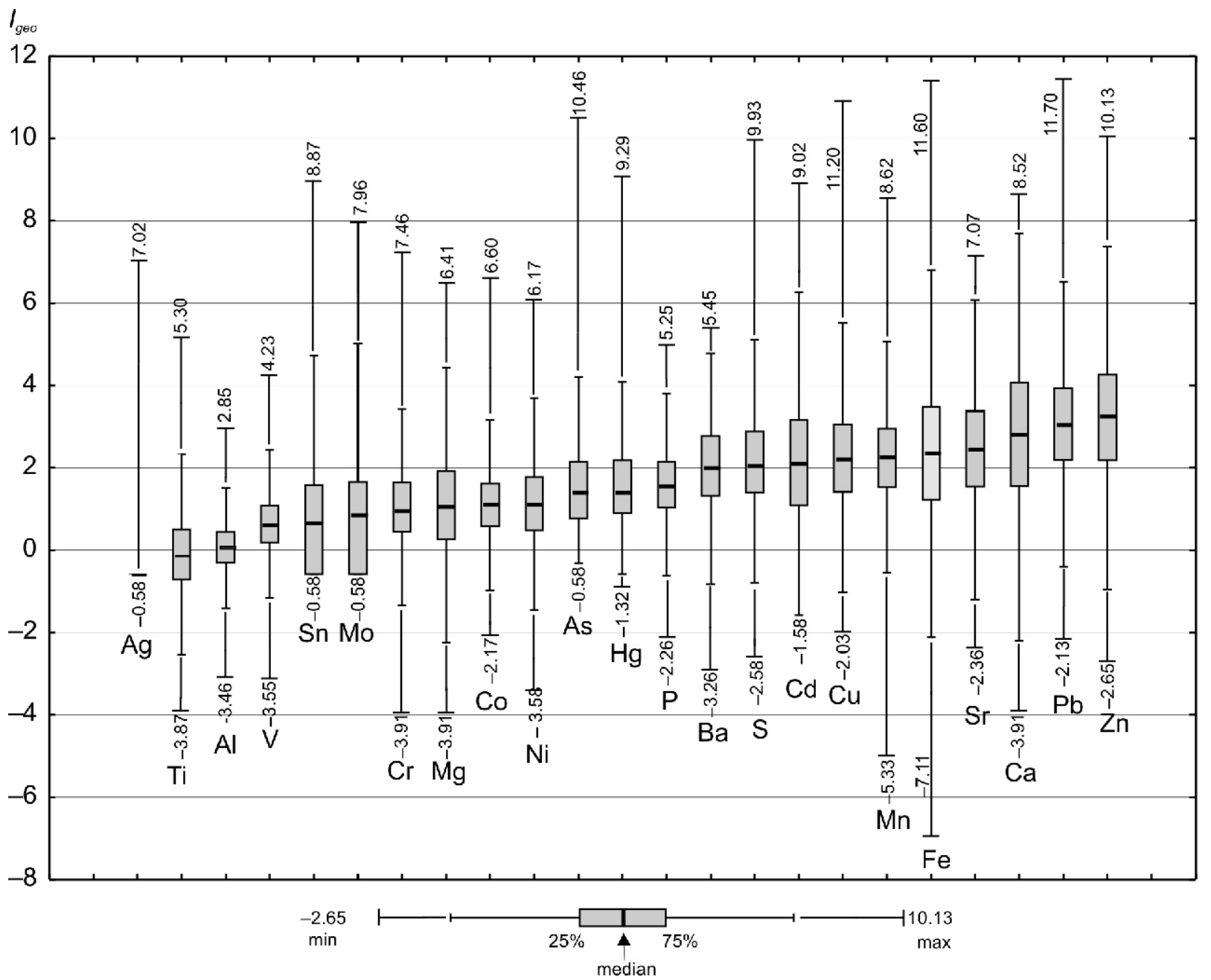

Fig. 7. Statistical parameters of geoaccumulation indexes of elements in topsoil $(0.0-0.3 \mathrm{~m})$

ment in $\mathrm{Mn}$ and $\mathrm{Sr}$ and over three-fold enrichment in $\mathrm{Zn}$ and $\mathrm{Ca}$ in comparison to the regional geochemical background.

4. High values of standard deviation (SD) of most elements indicate great data dispersion in relation to the average values. Low values of variation coefficients $(\mathrm{CV})$ for $\mathrm{Al}, \mathrm{Ba}, \mathrm{Ca}, \mathrm{Co} \mathrm{Fe}$, $\mathrm{Mg}, \mathrm{Ni}, \mathrm{P}, \mathrm{Sr}, \mathrm{Ti}$ and $\mathrm{V}$ indicate that their distribution in the soil is relatively homogeneous and therefore they are associated mainly with lithogenic origin. High CV values were found for As, $\mathrm{Cd}, \mathrm{Cr}, \mathrm{Cu}, \mathrm{Hg}, \mathrm{Mn}, \mathrm{Mo}, \mathrm{Pb}, \mathrm{S}, \mathrm{Sn}$ and $\mathrm{Zn}$, indicating heterogeneous distribution of these elements and their secondary introduction into the environment.

5. Based on multi-elemental principal component analyses the major factors allowing linking of the chemical element distributions to the main industries in the Upper Silesian Agglomeration are as follows: Factor F1 (Al-Ba-P-Sr) in topsoil and (Al-Ba-Co-Fe-P-Sr-Ti-V) in subsoil can be linked to their lithologic-anthropogenic origin and suggest that the main sources are the soil parent materials; Factor F2 (Ag-As-Cd-Pb-S-Zn) is associated predominantly with mining and processing of $\mathrm{Zn}-\mathrm{Pb}$ ores and zinc smelting and Factor F3 (Cr-Mo-Ni) group elements are related to the iron and steel industry.

6. Comparison of areas with the strongest anomalies of selected elements $(\mathrm{Cd}$, Mo and $\mathrm{Hg}$ ) in soil with the location of industrial plants shows that their most prolific sources are mine waste accumulations and tailings of $\mathrm{Zn}-\mathrm{Pb}$ ores and waste piles of historical zinc smelters (causing accumulation of $\mathrm{Zn}, \mathrm{Cd}, \mathrm{As}$, $\mathrm{Pb}$ and $\mathrm{S}$ ), modern iron and steel metallurgy (affecting dispersion of $\mathrm{Cr}, \mathrm{Mn}, \mathrm{Mo}, \mathrm{Cu}$ and $\mathrm{Sn}$ ) and coal combustion causing emission of $\mathrm{Hg}, \mathrm{S}$ and metal-containing particles.

7. The values of the indicators used to assess anthropogenic contamination of the soil (enrichment indicators EF and geo-accumulation indicators $I_{\text {geo }}$ ) indicated that the high concentrations of most metals, arsenic and sulphur in the topsoil are caused by past mining of $\mathrm{Zn}-\mathrm{Pb}$ ores and zinc and iron metallurgy. The EF and $I_{\text {geo }}$ values are characterized by good mutual convergence.

Acknowledgements. Firstly, we would like to thank T. Jerzykiewicz for fruitful discussions on different aspects of environment pollution, suggestions and editorial advice. Thanks are also due to W. Markowski for his help in developing the maps. We would like to thank A. Ladenberger and the second, anonymous reviewer for comments which significantly improved this paper. This study was supported by Project No. 22.1407.1302.00.1 from the National Fund for Environmental Protection and Water Management. The final editorial work was supported by PGI-NRI statutory funds (Project No. 62.9012.1911.00.0). 


\section{REFERENCES}

Acosta, J.A., Martinez-Martinez, S., Zornoza, R., Carmona, D.M., Kabas, S., 2011. Multivariate statistical and GIS-based approach to evaluate heavy metals behaviour in mine sites for future reclamation. Journal of Geochemical Exploration, 109 8-17.

Adamo, P., Arienzo, M., Bianco, M.R., Terribile, F., Violante, P., 2002. Heavy metal contamination of the soils used for stocking raw materials in the former ILVA iron-steel industrial plant of Bagnoli (southern Italy). Science of the Total Environment, 295 7-34.

Alary, J., Bourbon, P., Esclassan, J., Lepert, J.C., Vandaele, J., Klein, F., 1983. Zinc, lead, molybdenum contamination in the vicinity of an electric steelworks and environmental response to pollution abatement by bag filter. Water, Air and Soil Pollution, 20: 137-145.

Alloway, B.J., 2012. Sources of heavy metals and metalloids in soils. Environmental Pollution, 22: 11-50.

Barbieri, M., Sappa, G., Vitale, S., Parisse, B., Battistel, M., 2014 Soil control of trace metals concentrations in landfill: a case study of the largest landfill in Europe, Malagrotta, Rome. Journal of Geochemical Exploration, 143: 146-154.

Barbieri, M., 2016. The importance of Enrichment Factor (EF) and Geoaccumulation Index (Igeo) to evaluate the soil contamination. Journal of Geology \& Geophysics, 5: 1-4.

Basta, N.T., Gradwohl, R., 1998. Remediation of heavy metal-contaminated soil using rock phosphate (Oklahoma). Better Crops, 82: 29-31.

Basta, N.T., Gradwohl, R., Snethen, K.L., Schroder, J.L., 2001. Chemical immobilization of lead, zinc, and cadmium in smelter-contaminated soils using biosolids and rock phosphate. Journal of Environmental Quality, 30: 1222-1230.

Basta, N.T., McGowen, S.L., 2004. Evaluation of chemical immobilization treatments for reducing heavy metal transport in a smelter-contaminated soil. Environmental Pollution, 127: 73-82.

Bauerek, A., Cabala, J., Smieja-Król, B., 2009. Mineralogical alterations of $\mathrm{Zn}-\mathrm{Pb}$ flotation wastes of the Mississippi Valley Type ores (Southern Poland) and their impact on contamination of rain water runoff. Polish Journal of Environmental Studies, 18 781-788.

Bhattacharyya, S., Donahoe, R.J., Patel, D., 2009. Experimental study of chemical treatment of coal fly ash to reduce the mobility of priority trace elements. Fuel, 88: 1173-1184.

Blaser, P., Zimmermann, S., Luster, J., Shotyk, W., 2000. Critical examination of trace element enrichments and depletions in soils: As, $\mathrm{Cr}, \mathrm{Cu}, \mathrm{Ni}, \mathrm{Pb}$, and $\mathrm{Zn}$ in Swiss forest soils. The Science of the Total Environment, 249: 257-280.

Bojakowska, I., Sokołowska, G., 2001. Mercury in mineral raw materials exploited in Poland as potential sources of environmental pollution (in Polish with English summary). Biuletyn Państwowego Instytutu Geologicznego, 394: 5-54.

Buła Z., Kotas A., 1994. Geological Atlas of the Upper Silesian Coal Basin, Part III Structural Geological Maps. Polish Geological Institute.

Burchart-Korol, D., 2010. Environment evaluation of iron and steel production technologies based on LCA (in Polish with English summary). Prace Naukowe Głównego Instytutu Górnictwa, Górnictwo i Środowisko, 3: 5-13.

Cabała, J., 1996. Concentrations of trace elements in $\mathrm{Zn}-\mathrm{Pb}$ ores and possibilities of their transfer to waste deposits (in Polish with English summary). Prace Naukowe Głównego Instytutu Górnictwa, seria Konferencje, 13: 17-32.

Cabała, J., 2009. Heavy metals in ground soil environment of the Olkusz area of $\mathrm{Zn}-\mathrm{Pb}$ ore exploitation (in Polish with English summary). Wydawnictwo Uniwersytetu Śląskiego, Katowice.

Cabała, J., Teper, L., 2007. Metalliferous constituents of rhizosphere soils contaminated by $\mathrm{Zn}-\mathrm{Pb}$ mining in southern Poland. Water, Air and Soil Pollution, 178: 351-362.
Cappuyns, V., Swennen, R., Vandamme, A., Niclaes M., 2005. Environmental impact of the former $\mathrm{Pb}-\mathrm{Zn}$ mining and smelting in East Belgium. Journal of Geochemical Exploration, 88: 6-9.

Chłopecka, A., Bacon, J.R., Wilson, J., Kay, J., 1996. Forms of cadmium, lead and zinc in contaminated soils from southwest Poland. Journal of Environmental Quality, 25: 69.

Cui, Y.J., Zhu, Y.G., Zhai, R.H., Chen, D.Y., Huang, Y.Z., Qiu, Y., Liang, J.Z., 2004. Transfer of metals from soil to vegetables in an area near a smelter in Nanning, China. Environment International, 30: 785-791.

Degenhardt, 0., 1870. Der Oberschlesian-Polnische-Bergdistrict mit Hinweglassung des Diluviums. Karte von Oberschlesien 1:100000. Verlag der Landkarten Handlung von J.H. Neumann, Berlin.

Deonarine, A., Kolker, A., Doughten, M.W., 2015. Trace elements in coal ash. U.S. Geological Survey Fact Sheet 2015-3037: 1-6.

De Volder, P.S., Brown, S.L., Hesterberg, D., Pandya, K., 2003. Metal bioavailability and speciation in a wetland tailings repository amended with biosolids compost, wood ash, and sulfate. Journal of Environmental Quality, 32: 851-864.

De Vos, W., Tarvainen, T. (eds.), 2006. Geochemical Atlas of Europe. Part 2, Geological Survey of Finland, Espoo.

Diehl, S.F., Goldhaber, M.B., Hatch, J.R., 2004. Modes of occurrence of mercury and other trace elements in coals from the warrior field, Black Warrior Basin, Northwestern Alabama. International Journal of Coal Geology, 59: 193-208.

Dombek, V., Gembalová, L., Matýsek, D., Drobek, L., Bzowski, Z., Ženatý, L., Seibert, R., 2015. Impact of selected post-mining and metallurgical dumps on air pollution on sites in the Czech Republic and Poland. GeoScience Engineering, 61: 24-36.

Duriasz, I., Cupiał, A., 2009. Prognoza oddziaływania na środowisko dla zmiany studium uwarunkowań i kierunków zagospodarowania przestrzennego miasta Świętochłowice (in Polish), https://www.swietochlowice.pl/bip/gpn/zal7.pdf (date of last access: 27.04.2020).

Ekiert, F., 1971. Geology of the zinc and lead ore deposits in the north-eastern margin of the Upper Silesian Coal Basin (in Polish with English summary). Biuletyn Instytutu Geologicznego, 241: 47-56.

Everhart, J.L., McNear, D.Jr., Peltier, E, van der Lelie, D., Chaney, R.L, Sparks, D.L., 2006. Assessing nickel bioavailability in smelter-contaminated soils. Science of the Total Environment, 367: 732-744.

Filippelli, G.M, Laidlaw, M.A.S., 2010. The elephant in the playground: Confronting lead-contaminated soils as an important source of lead burdens to urban populations. Perspectives in $\mathrm{Bi}$ ology and Medicine, 53: 31-45.

Filippelli, G.M, Morrison, D., Cicchella, D., 2012. Urban geochemistry and human health. Elements, 8: 439-444.

Fernandez-Turiel, J.L., Aceńolaza, P., Medina, M.E., Llorens, J.F., Sardi, F., 2001. Assessment of a smelter impact area using surface soils and plants. Environmental Geochemistry and Health, 23: 65-78.

FriesI-Hanl, W., Platzer, K., Horak, O., Gerzabek, M.H., 2009. Immobilising of $\mathrm{Cd}, \mathrm{Pb}$, and $\mathrm{Zn}$ contaminated arable soils close to a former $\mathrm{Pb} / \mathrm{Zn}$ smelter: a field study in Austria over 5 years. Environmental Geochemistry and Health, 31: 581-594.

Fuge, R., Pearce, F.M., Pearce, N.J.G., Perkins, W.T., 1993. Geochemistry of $\mathrm{Cd}$ in the secondary environment near abandoned metalliferous mines, Wales. Applied Geochemistry, Supplement, 2: 29-35.

Gade, D., 2015. Mercury Emissions from Coal-Fired Powerplants. Environmental Management \& Risk Assessment (PH 560). Paper 4 https://pdfs.semanticscholar.org/9294/67546a642c57592f97ceb9 49dc93b9160cf7.pdf

Gałkiewicz, T., Śliwiński, S., 1985. Geological characteristics of the Silesian-Cracovian lead-zinc ore deposits (in Polish with 
English summary). Annales Societatis Geologorum Poloniae, 53: 63-90.

Gäbler, H.E., Schneider, J., 2000. Assessment of heavy-metal contamination of floodplain soils due to mining and mineral processing in the Harz Mountains, Germany. Environmental Geology, 39: 774-782.

Górecka, E., 1993. Geological setting of the Silesian-Cracow Zn-Pb deposits. Geological Quarterly, 37 (2): 127-146.

Górecka, E., 1996. Mineral sequence development in the $\mathrm{Zn}-\mathrm{Pb}$ deposits of the Silesian-Cracow area, Poland. Prace Państwowego Instytutu Geologicznego, 154: 26-36.

Grzechnik, Z., 1978. History of previous exploration and exploitation (in Polish with English summary). Prace Instytutu Geologicznego, 83: 23-41.

Guo-Li, Y., Tian-He, S., Peng, H., Jun, L., 2013. Environmental geochemical mapping and multivariate geostatistical analysis of heavy metals in topsoils of a closed steel smelter: Capital Iron \& Steel Factory, Beijing, China. Journal of Geochemical Exploration, 130: 15-21.

Harańczyk, C., 1962. Ore minerals of Silesia-Cracow zinc and lead deposits (in Polish with English summary). Prace Geologiczne, 8: $1-74$

Heijlen, W., Muchez, P., Banks, D.A., Schneider, J., Kucha, H., Keppens, E., 2003. Carbonate-hosted $\mathrm{Zn}-\mathrm{Pb}$ deposits in Upper Silesia, Poland: origin and evolution of mineralizing fluids and constrains on genetic models. Economic Geology, 98: 911-932.

Hławiczka, S., 2008. Mercury in the atmospheric environment (in Polish with English summary). Wyd. Instytutu Podstaw Inżynierii Środowiska PAN, Zabrze.

Jablonska, M., Frans, J., Rietmeijer, J., Janeczek, J., 2001. Fine-grained barite in coal fly ash from the Upper Silesian Industrial Region. Environmental Geology, 40: 941-948.

Jureczka, J., Dopita, M., Gałka, M., Krieger, W., Kwarciński, J., Martinec P., 2005. Geological Atlas of Coal Deposits of the Polish and Czech Parts of the Upper Silesian Coal Basin. Polish Geological Institute, Warsaw.

Kabata-Pendias, A., Mukherjee, A., 2007. Trace Elements from Soil to Human. Springer-Verlag, Berlin Heidelberg.

Kachenko, A.G., Singh, B., 2006. Heavy metal contamination in vegetables grown in urban and metal smelter contaminated sites in Australia. Water, Air and Soil Pollution, 169: 101-123.

Kalembkiewicz, J., Sočo, E., 2009. Industrial fly ash as a potential source of molybdenum emission (in Polish with English summary). Ochrona Środowiska i Zasobów Naturalnych, 40: 601-607.

Karczewska, A., Szerszen, L., Kabala, C., 1998. Forms of selected heavy metals and their transformation in soils polluted by the emissions from copper smelters. Advanced GeoEcology, 31: 705-712.

Kierczak, J., Bril, H., Neel, C., Puziewicz, J., 2010. Pyrometallurgical slags in Upper and Lower Silesia (Poland): from environmental riska to use of slag-based products - a review. Archives of Environmental Protection, 36: 11-126.

Klimek, B., Sitarz, A., Choczyński, M., Niklińska, M., 2016. The effects of heavy metals and total petroleum hydrocarbons on soil bacterial activity and functional diversity in the Upper Silesia Industrial Region (Poland). Water, Air and Soil Pollution, 227: 265.

Kokowska-Pawłowska, M., 2016. Relationship of the trace elements content with minerals and organic matter of the lithotypes from the coal seam 308 (Orzesze beds) USCB (in Polish with English summary). Systemy Wspomagania w Inżynierii Produkcji, 5: 109-120.

Kolker, A., Senior, C.L., Quick, J.C., 2006. Mercury in coal and the impact of coal on mercury emissions from combustion systems. Applied Geochemistry, 21: 1821-1836.

Krzak, M., Paulo, A., 2018. Modern trade standards for steel raw materials. Gospodarka Surowcami Mineralnymi - Mineral Resources Management, 34: 25-50.

Kucha, H., 2003. Mississippi Valley Type Zn -Pb deposits of Upper Silesia, Poland. In: Europe's Major Base Metal Deposits (eds. J.G. Kelly, C.J. Andrew, J.H. Ashton, M.B. Bolland, G. Earls, L.F.
Fuscardi and G. Stanley): 253-271. Irish Association for Economic Geology.

Lis, J., Pasieczna, A., 1995. Geochemical Atlas of Upper Silesia (1:200 000). Polish Geological Institute.

Lis, J., Pasieczna, A., 2005. Factor analysis for geochemical characteristic of soils in the mining and smelting area (Sławków-Bolesław region). Prace Specjalne Polskiego Towarzystwa Mineralogicznego, 25: 146-149.

Loska, K., Wiechuła, D., Korus, I., 2004. Metal contamination of farming soils affected by industry. Environmental International, 30: 159-165.

Lu, A., Wang, J., Qin, X., Wang, K., Han, P., Zhang, S., 2012. Multivariate and geostatistical analyses of the spatial distribution and origin of heavy metals in the agricultural soils in Shunyi, Beijing, China. Science of the Total Environment, 425: 66-74.

Majorczyk, R., 1986. 125 lat Zakładów Górniczo-Hutniczych Orzeł Biały (in Polish). Rudy Metale, 31: 462-469.

Merrington, G., Alloway, B.J., 1994. The transfer and fate of Cd, $\mathrm{Cu}$ and $\mathrm{Zn}$ from two historic metalliferous mine sites in the UK. Applied Geochemistry, 9: 677-687.

Michalik, J. (ed.), 2003. Program Ochrony Środowiska wraz z Planem Gospodarki Odpadami dla Miasta Chorzów na lata 2004-2007 wraz z prognoza do roku 2011 (in Polish), http://www.bip.chorzow.eu/add_www/file/prog_os.pdf

Mikulski, S.Z., Oszczepalski, S., Sadłowska, K., Chmielewski, A., Małek, R., 2020. Trace element distributions in the $\mathrm{Zn}-\mathrm{Pb}$ (Mississippi Valley-Type) and Cu-Ag (Kupferschiefer) sediment-hosted deposits in Poland. Minerals, 75: https://doi.org/10.3390/min10010075

Moir, A.M., Thornton, I., 1989. Lead and cadmium in urban allotment garden soils and vegetables in the United Kingdom. Environmental Geochemistry and Health, 11: 113-119.

Molenda, D., 1972. Kopalnie rud ołowiu na terenie złóż śląsko-krakowskich od XVI do XVIII wieku (in Polish). Z dziejów postępu technicznego eksploatacji kruszców: 25-31. Wyd. Ossolineum, Wrocław.

Müller, G., 1969. Index of geoaccumulation in sediments of the Rhine River. Geojournal, 2: 108-118.

Nachtegaal, M., Marcus, M.A., Sonke, J.E., Vangronsveld, J., Livi, K.J.T., van der Lelie, D., Sparks, D.L., 2005. Effects of in situ remediation on the speciation and bioavailability of zinc in a smelter contaminated soil. Geochimica et Cosmochimica Acta, 69: 4649-4664.

Nagajyoti, P.C., Lee, K.D., Sreekanth, T.V.M., 2010. Heavy metals, occurrence and toxicity for plants: a review. Environmental Chemistry Letters, 8: 199-216.

Nannoni, F., Protano, G., Riccobono, F., 2011. Uptake and bioaccumulation of heavy elements by two earthworm species from a smelter contaminated area in northern Kosovo. Soil Biology and Biochemistry, 43: 2359-2367.

Navarro, M.C., Pérez-Sirvent, C., Martínez-Sánchez, M.J., Vidal, J., Marimón, J., 2006. Lead, cadmium and arsenic bioavailability in the abandoned mine site of Cabezo Rajao (Murcia, SE Spain). Chemosphere, 63: 484-489.

Niemierowski, W., 1983. Dwa wieki huty „Zabrze” 1782-1982 (in Polish). Zabrze.

Ottesen, R.T., Birke, M., Finne, T.E., Gosar, M., Locutura, J., Reimann, C., Tarvainen, T., the GEMAS Project Team., 2013. Mercury in European agricultural and grazing land soils. Applied Geochemistry, 33: 1-12.

Owczarek, J., Syska, A., Caban, E., Szala, M., Szymańska, J., Woźniakowska, A., 2012. Wstępne sprawozdanie z inwentaryzacji obiektów przemysłowych w województwie śląskim (in Polish). Wyd. Śląskiego Centrum Dziedzictwa Kulturowego, Katowice.

Pasieczna A. (ed.), 2016. Detailed Geochemical Map of Upper Silesia. Polish Geological Institute, http://www.mapgeochem.pgi.gov.pl/forward.html

Pasieczna, A., Bojakowska, I., Nadłonek, W., 2017. The impact of anthropogenic factors on the occurrence of molybdenum in stream and river sediments of central Upper Silesia (Southern 
Poland). Environmental Protection and Natural Resources, 28 16-26.

Pandey, V.C., Abhilash, P.C., Upadhyay, R.N., Tewari, D.D., 2009 Application of fly ash on the growth performance and translocation of toxic heavy metals within Cajanus cajan L.: implication for safe utilization of fly ash for agricultural production. Journal of Hazardous Materials, 166: 255-259.

Paulo, A., Strzelska-Smakowska, B., 2000. Rudy metali nieżelaznych i szlachetnych (in Polish). Wydawnictwo $\mathrm{AGH}$, Kraków.

Paulson, A.J., 1997. The transport and fate of $\mathrm{Fe}, \mathrm{Mn}, \mathrm{Cu}, \mathrm{Zn}, \mathrm{Cd}$ $\mathrm{Pb}$, and $\mathrm{SO}_{4}$ in a groundwater plume and in downstream surface water in the Coeur d'Alene mining district, Idaho, U.S.A. Applied Geochemistry, 12: 447-464.

Pelfrêne, A., Waterlot, C., Mazzuca, M., Nisse, C., Bidar, G., Douay, F., 2011. Assessing $\mathrm{Cd}, \mathrm{Pb}, \mathrm{Zn}$ human bioaccessibility in smelter-contaminated agricultural topsoils (northern France). Environmental Geochemistry and Health, 33: 477-493.

Piwocki, M., Przeniosło, S., 2004. Mineral raw materials and commodities of Poland. Przegląd Geologiczny, 52: 744-752.

PN-ISO 10390, 1997. Polska Norma PN-ISO 10390, Polski Komite Normalizacyjny. Jakość gleby. Oznaczanie $\mathrm{pH}$.

Reimann, C., de Caritat, P., 1998. Chemical elements in the environment - factsheets for the geochemist end environmental scientist. Springer, Berlin Heidelberg.

Reimann, C., de Caritat, P., 2000. Intrinsic flaws of element enrichment factors (EFs) in environmental geochemistry. Environmental Science \& Technology, 34: 5084-5091.

Reimann, C., de Caritat, P., 2017. Establishing geochemical background variation and threshold values for 59 elements in Australian surface soil. Science of the Total Environment, $\mathbf{5 7 8}$ 633-648.

Reimann, C., Filzmoser, P., Garret, R.G., 2005. Background and threshold: critical comparison of methods of determination. Science of the Total Environment, 346: 1-16.

Rice, K.M., Walker, E.M., Wu, M., Gillette, Ch., Blough, E.R., 2014. Environmental mercury and its toxic effects. Journal of Preventive Medicine \& Public Health, 47: 74-83.

Rożek, D., Nadłonek, W., Cabała, J., 2015. Forms of heavy metals $(\mathrm{Zn}, \mathrm{Pb}, \mathrm{Cd}$ ) occurring in rhizospheres from the areas of former and contemporary $\mathrm{Zn}-\mathrm{Pb}$ ore mining. Mining Science, 22 (Special Issue 2): 125-138.

Różkowska, A., Ptak, B., 1995. Bar w węglach kamiennych Górnego Śląska (in Polish). Przegląd Geologiczny, 43 223-226.

Sass-Gustkiewicz, M., 1997. Revised and completed paragenetic order of minerals in the Pomorzany lead-zinc deposit, Upper Silesian district, Poland. Mineralogia Polonica, 28: 67-80.

Smedley, P.L., Kinniburgh, D.G., 2017. Molybdenum in natural waters: a review of occurrence, distributions and controls. Applied Geochemistry, 84: 387-432.

Smieja-Król, B., Bauerek, A. 2015. Controls on trace-element concentrations in the pore waters of two Sphagnum-dominated mires in southern Poland that are heavily polluted by atmospheric deposition. Journal of Geochemical Exploration, 151 $57-65$.

Sordoń-Kulibaba, B., 2010. Program ochrony środowiska dla miasta Świętochłowice (in Polish), https://www.swietochlowice.pl/files/PDF/programy_ekologiczne/POS_aktualizacja.pdf

Sulimierski, F., Chlebowski B., Walewski W. (eds.), 1880-1914. Słownik geograficzny Królestwa Polskiego i innych krajów słowiańskich (in Polish). Wyd. Kasa im. Józefa Mianowskiego, Warszawa.
Sutherland, R.A., Tolosa, C.A, Tack, F.M.G., Verloo, M.G., 2000. Characterization of selected element concentrations and enrichment ratios in background and anthropogenically impacted roadside areas. Archives of Environmental Contamination and Toxicology, 38: 428-438.

Swennen, R., Van Keer, I., De Vos, W., 1994. Heavy metal contamination in overbank sediments of the Geul river (East Belgium): Its relation to former $\mathrm{Pb}-\mathrm{Zn}$ mining activities. Environmental $\mathrm{Ge}$ ology, 24: 12-21.

Szczech, B., 2003. Siedemnastowieczny transumpt Fundacji Łagiewnickiej dla kościoła mariackiego w Bytomiu (1495) (in Polish), http://www.sbc.org.pl/Content/129556/4_Posortowane_013.pdf

Szczepańska, J., Twardowska, I., 1999. Distribution and environmental impact of coal-mining wastes in Upper Silesia, Poland. Environmental Geology, 38: 249-258.

Szpadt, R. (ed.), 1994. Zanieczyszczenie środowiska rtęcią i jej związkami (in Polish). Biblioteka Monitoringu Środowiska, Warszawa.

Szulc, W., 2013. Transformacja polskiego hutnictwa żelaza do gospodarki wolnorynkowej (in Polish). Wydawnictwo Instytutu Metalurgii Żelaza, Gliwice.

Szuwarzyński, M., 1996. Ore bodies in the Silesian-Cracow Zn-Pb ore district, Poland. Prace Państwowego Instytutu Geologicznego, 154: 9-24.

Taylor, M.P., Mackay, A.K, Hudson-Edwards, K.A, Holz, E., 2010. Soil $\mathrm{Cd}, \mathrm{Cu}, \mathrm{Pb}$ and $\mathrm{Zn}$ contaminant, around Isa City, Queensland, Australia: potential sources and risks to human health. Applied Geochemistry, 25: 841-855.

Tyszka, R., Kierczak, J., Pietranik, A., Ettler, V., Mihaljevič, M. 2014. Extensive weathering of zinc smelting slag in a heap in Upper Silesia (Poland): potential environmental risks posed by mechanical disturbance of slag deposits. Applied Geochemistry, 40: 70-81.

Viets, J.G., Leach, D.L., Lichte, F.E., Hopkins, R.T., Gent, C.A., Powell, J.W., 1996. Paragenetic and minor- and trace-element studies of Mississippi Valley type ore deposits of the Silesian-Cracow district, Poland. Prace Państwowego Instytutu Geologicznego, 154: 51-71.

Walerjański, D., 2006. Zabrze krok po kroku (in Polish). Zabrze.

Wong, C.S.C, Li, X., Thornton, I., 2006. Urban environmental geochemistry of trace metals. Environmental Pollution, 142: 1-16.

Wuana, R.A., Okieimen, F.E., 2011. Heavy Metals in Contaminated Soils: A Review of Sources, Chemistry, Risks and Best Available Strategies for Remediation. International Scholarly Research Network ISRN Ecology.

Yudovich, Y.E., Ketris, M.P., 2005. Mercury in coal: a review - Part 1. Geochemistry. International Journal of Coal Geology, 62: 107-134.

Zapotoczna-Sytek, G., Łaskawiec, K., Gembarowski, P., Małolepszy, J., Szymczak, J., 2013. Popioły lotne nowej generacji do produkcji autoklawizowanego betonu komórkowego (in Polish). Instytut Ceramiki i Materiałów Budowlanych, Warszawa.

Zhang, J., Liu, C.L., 2002. Riverine composition and estuarine geochemistry of particulate metals in China-weathering features, anthropogenic impact and chemical fluxes. Estuarine, Coastal and Shelf Science, 54: 1051-1070.

Ziętek-Kruszewska, A., 1978. Mineralogical characteristics of the Triassic sulphides (in Polish with English summary). Prace Instytutu Geologicznego, 83: 211-215.

Żabiński, W., 1960. The mineralogical characteristic of the oxidation zone of Silesia-Cracow zinc and lead deposits (in Polish with English summary). Prace Geologiczne, 1: 1-73. 